\title{
ANALISIS RASIO KEUANGAN TERHADAP FINANCIAL DISTRESS DENGAN STRUKTUR KEPEMILIKAN SEBAGAI VARIABEL MODERASI
}

\author{
Felicia Komala \\ Yustina Triyani*
}

Program Studi Akuntansi, Kwik Kian Gie School of Business, Jl. Yos Sudarso Kav. 87, Jakarta 14350

\begin{abstract}
Financial distress is step decrease in the company's financial condition before the company went bankrupt. Financial distress can be analyzed through financial ratio and ownership structure of company. This study used logistic regression analysis. The sampling technique is non-probability sampling using purposive sampling method. The study sample consisted of 70 companies on Stock Exchange from 2015-2017 period. Based on regression, Grover, Springate model showed that the model is able to predict value of observation. The results indicate there is sufficient evidence tends to leverage positively affects both financial distress with Grover and Springate model, firms growth tend to negatively affect financial distress with Springate model, and institutional ownership tends to weaken the influence of leverage to financial distress with Springate model. On the other hand, there is not enough evidence that the firm's growth tends to negatively affect the financial distress with Grover model. Managerial ownership has no effect in relation moderate leverage and growth of firm towards better financial distress with Grover and Springate model. Institutional ownership has no effect in moderating leverage of financial distress relationship with Grover model. Institutional ownership has no effect on firm's growth to moderate the relationship financial distress with Grover or Springate model.
\end{abstract}

Keywords : Financial ratio analysis, Ownership structure, Financial distress

\begin{abstract}
Abstrak
Financial distress merupakan tahap penurunan kondisi keuangan perusahaan sebelum perusahaan bangkrut. Financial distress dapat dianalisis melalui rasio keuangan dan struktur kepemilikan suatu perusahaan. Teknik analisis data yang digunakan dalam penelitian ini adalah analisis regresi logistik. Teknik pengambilan sampel yang dilakukan adalah non-probability sampling dengan menggunakan purposive sampling method. Sampel penelitian ini terdiri atas 70 perusahaan manufaktur yang terdaftar di BEI periode 2015-2017. Berdasarkan uji kelayakan model regresi baik dengan model Grover maupun model Springate menunjukkan bahwa model mampu memprediksi nilai observasinya. Hasil penelitian ini menunjukkan bahwa terdapat cukup bukti leverage cenderung berpengaruh positif terhadap financial distress baik dengan model Grover maupun model Springate, pertumbuhan perusahaan cenderung berpengaruh negatif terhadap financial distress dengan model Springate, dan kepemilikan institusional cenderung memperlemah pengaruh leverage terhadap financial distress dengan model Springate. Di sisi lain, tidak terdapat cukup bukti bahwa pertumbuhan perusahaan cenderung berpengaruh negatif terhadap financial distress dengan model Grover. Kepemilikan manajerial tidak berpengaruh dalam memoderasi hubungan leverage dan pertumbuhan perusahaan terhadap financial distress baik dengan model Grover dan model Springate. Kepemilikan institusional tidak berpengaruh dalam memoderasi hubungan leverage terhadap financial distress dengan model Grover. Kepemilikan institusional tidak berpengaruh dalam memoderasi hubungan pertumbuhan perusahaan terhadap financial distress baik dengan model Grover maupun model Springate.
\end{abstract}

Kata Kunci : Analisis rasio keuangan, Struktur kepemilikan, financial distress

\footnotetext{
*Alamat kini: Institut Bisnis dan Informatika Kwik Kian Gie, Jl. Yos Sudarso Kav. 87, Jakarta 14350

Penulis untuk Korespondensi: Telp. (021) 65307062 Ext. 708, Email: yustina.kamidi@kwikkiangie.ac.id
} 


\section{Pendahuluan}

Kondisi perekonomian di Indonesia saat ini sedang memasuki masa krisis, dimana kondisi ini sangat rawan terhadap terjadinya kesulitan keuangan (financial distress) pada beberapa Perusahaan Nasional. Pada tahun 2018, telah terjadi krisis ekonomi di Indonesia yang ditandai dengan melemahnya kurs Rupiah terhadap Dollar Amerika Serikat. Kurs rupiah di pasar spot kembali melemah sebesar 0,24\% menjadi Rp 14.680 per dollar AS. Selain itu, kurs tengah rupiah di Bank Indonesia juga ikut melemah $0,15 \%$ ke level $\mathrm{Rp} 14.655$ per dollar AS. Melemahnya nilai rupiah menyebabkan Bank Indonesia (Bank Central) menaikkan tingkat bunga. (Sumber : http://jabar.tribunnews.com). Adanya peningkatan bunga yang ditetapkan Bank Indonesia menyebabkan perusahaan harus menanggung biaya bunga yang lebih tinggi, sehingga potensi perusahaan dalam mengembalikan jumlah pinjamannya kepada bank menjadi rendah.

Pada tahun 2018, terdapat empat perusahaan besar di Indonesia yang dinyatakan pailit (Sumber : https://www.merdeka.com). Salah satu perusahaan besar di Indonesia yang dinyatakan pailit pada tahun 2018 adalah PT Sariwangi Agricultural Estate Agency (SAEA) bersama perusahaan afiliasinya PT Maskapai Perkebunan Indorub Sumber Wadung (MPISW). Kepailitan yang dialami kedua perusahaan tersebut disebabkan karena terjeratnya hutang yang mencapai $\mathrm{Rp}$ 1,5 triliun kepada sejumlah kreditur. Timbulnya hutang tersebut dikarenakan kedua perusahaan gagal berinvestasi untuk meningkatkan produksi perkebunan. Selain itu, pembayaran hutang yang tersendat menyebabkan sejumlah kreditur mengajukan tagihan. Namun, dikarenakan SAEA dan MPISW tidak sanggup membayar cicilan tersebut, maka pada 17 Oktober 2018, Majelis Hakim Pengadilan Niaga Jakarta Pusat mengabulkan permohonan pembatalan homologasi dari salah satu kreditur, yaitu PT Bank ICBC Indonesia terhadap SAEA dan MPISW (Sumber : https://ekonomi.kompas.com).

Selama tahun 2017, terdapat delapan perusahaan di Indonesia yang dinyatakan pailit. Perusahaan-perusahaan tersebut diantaranya PT
Dwi Aneka Jaya Kemasindo Tbk. (DAJK) dan PT Asia Paper Mills. PT Dwi Aneka Jaya Kemasindo Tbk. (DAJK) merupakan perusahaan yang bergerak pada bidang kemasan karton dan kertas. DAJK resmi dinyatakan pailit pada 22 November 2017 setelah majelis hakim mengabulkan permohonan pembatalan perdamaian yang dilayangkan oleh Bank Mandiri. Hutang yang dimiliki DAJK mencapai Rp 1,1 triliun dan porsi tagihan Bank Mandiri hampir separuhnya, yakni Rp 428,27 miliar. Sedangkan, PT Asia Paper Mills merupakan perusahaan yang memproduksi kertas dan plastik kemasan telah dinyatakan pailit oleh Pengadilan Niaga Jakarta Pusat pada 7 Agustus 2017. Hal ini dikarenakan PT Asia Paper Mills menyisakan total hutang senilai Rp 568 miliar kepada para kreditur, salah satunya hutang kepada Bank Mandiri dengan nilai Rp 370,64 miliar. (Sumber : http://kabar24.bisnis.com).

Kesulitan keuangan dapat diukur dan dilihat dari laporan keuangan suatu perusahaan. Kesulitan keuangan dapat diketahui dengan menganalisis rasio keuangan suatu perusahaan berdasarkan laporan keuangan perusahaan tersebut. Analisis rasio keuangan yang biasanya digunakan dalam memprediksi financial distress antara lain leverage dan pertumbuhan perusahaan.

Leverage adalah rasio yang timbul dari aktivitas pengggunaan dana perusahaan yang berasal dari pihak ketiga dalam bentuk hutang. Pendanaan yang dilakukan perusahaan dalam bentuk hutang ini akan menimbulkan kewajiban bagi perusahaan untuk melunasi hutang tersebut. Jumlah hutang yang semakin tinggi akan mengakibatkan bunga yang ditanggung semakin tinggi (Rohmadini et al., 2018). Jika perusahaan tidak mampu membayar hutang yang dimilikinya maka kegiatan operasional perusahaan dapat terganggu sehingga pendapatan perusahaan berkurang. Kondisi ini dapat memicu terjadinya financial distress.

Pertumbuhan perusahaan merupakan gambaran kemampuan perusahaan dalam meningkatkan penjualannya dari waktu ke waktu. Pertumbuhan perusahaan biasanya diukur menggunakan rasio pertumbuhan penjualan. Rasio tersebut akan dijadikan pertimbangan investor untuk melakukan investasi pada suatu 
perusahaan. Perusahaan yang mempunyai pertumbuhan penjualan yang tinggi menunjukkan bahwa perusahaan telah berhasil menjalankan strategi dan pemasaran penjualan produk (Widarjo dan Setiawan, 2009). Hal tersebut akan meminimalkan potensi terjadinya financial distress dikarenakan perusahaan dapat mempertahankan posisi ekonominya.

Selain dilihat dari laporan keuangan, kesulitan keuangan suatu perusahaan dapat dilihat melalui sistem pengelolaan suatu perusahaan yaitu good corporate governance. Indikator-indikator good corporate governance yang digunakan dalam memprediksi financial distress seperti kepemilikan manjerial dan kepemilikan institusional.

Kepemilikan manajerial adalah proporsi kepemilikan saham yang dimiliki manajemen (direksi atau karyawan). Kepemilikan manajerial yang semakin besar menyebabkan tanggung jawab manajemen terhadap pengelolaan perusahaan dalam pengambilan keputusan bagi kepentingan perusahaan juga semakin besar. Dengan tingginya tanggung jawab manajemen diharapkan potensi perusahaan mengalami financial distress dapat terhindar (Triwahyuningtias dan Muharam, 2012).

Kepemilikan institusional adalah kepemilikan saham yang dimiliki institusi seperti perusahaan efek, perusahaan asuransi, perbankan, perusahaan investasi, dana pensiun, dan kepemilikan institusi lainnya. Kepemilikan institusional berfungsi untuk meningkatkan pengawasan yang lebih optimal terhadap kinerja manajemen perusahaan sehingga potensi terjadinya kesulitan keuangan dapat diminimalisir (Triwahyuningtias dan Muharam, 2012). Tingginya pengawasan terhadap manajemen yang dilakukan oleh institusi akan mengurangi potensi terjadinya kesulitan keuangan.

Penelitian ini bertujuan untuk mencari bukti empiris pengaruh leverage dan pertumbuhan perusahaan terhadap financial distress dengan kepemilikan manajerial dan kepemilikan institusional sebagai variabel moderasi. Penelitian ini diharapkan bisa bermanfaat bagi perusahaan untuk mengkaji faktor-faktor dalam memprediksi kondisi keuangannya sehingga dapat terhindar dari kebangkrutan. Hasil penelitian ini juga bisa bermanfaat sebagai sumber referensi bagi penelitian selanjutnya.

\section{Landasan Teori}

\section{Teori Keagenan}

Teori keagenan menggambarkan hubungan antara pemegang saham (principal) dan manajemen (agent) dimana keduanya memiliki tugas masing-masing dalam menjalankan suatu bisnis. Pengaturan ini tidak bekerja dengan baik ketika agen membuat keputusan yang tidak sejalan dengan kepentingan prinsipal. Konflik yang timbul antara prinsipal dan agen di mana agen cenderung lebih mementingkan tujuan individu dibandingkan dengan tujuan perusahaan disebut agency problem. Salah satu penyebab timbulnya agency problem adalah adanya asimetri informasi (asymmetrical information). Agen selaku pengelola perusahaan akan lebih mengetahui informasi internal dan prospek perusahaan di masa yang akan datang dibanding prinsipal sehingga kemungkinan besar agen tidak selalu bertindak sesuai dengan keinginan prinsipal dalam mewujudkan tujuan perusahaan (Jensen dan Meckling, 1976). Adanya konflik antara agen dengan prinsipal akan memicu timbulnya biaya keagenan (agency cost).

\section{Laporan Keuangan}

Laporan keuangan merupakan hasil akhir dari siklus akuntansi yang menggambarkan kondisi keuangan dan hasil operasi suatu perusahaan. Laporan keuangan sangat berguna untuk memberikan informasi tentang kondisi keuangan dan hasil operasi suatu perusahaan kepada pihak dalam (internal) perusahaan yaitu manajemen dan pemilik perusahaan serta pihak luar (eksternal) perusahaan yang berkepentingan terhadap perusahaan yaitu investor, kreditur, dan pemerintah. Laporan keuangan sering disebut sebagai "language of business" karena digunakan untuk berkomunikasi dengan pihak-pihak yang mempunyai kepentingan dengan data keuangan perusahaan dalam pertimbangan pengambilan keputusan-keputusan ekonomi (Sugiono dan Untung, 2016 : 1-3). Laporan keuangan digunakan untuk mengetahui keberhasilan manajemen dalam mengelola perusahaan sehingga laporan keuangan merupakan wujud 
pertanggungjawaban manajemen kepada pemilik perusahaan.

\section{Analisis Rasio Keuangan}

Rasio keuangan merupakan alat yang digunakan dalam menganalisis keuangan. Penggunaan rasio keuangan sebagai alat analisis harus memperhatikan beberapa hal agar interpretasi hasil perhitungan rasio keuangan dapat menghasilkan kesimpulan yang lebih tepat (Hery, 2016 : 18-19). Analisis rasio keuangan ini digunakan untuk menggambarkan suatu hubungan dan perbandingan antara jumlah satu akun dengan jumlah akun yang lain dalam laporan keuangan, baik dalam neraca maupun laporan laba rugi. Baik atau buruknya keadaan atau posisi keuangan suatu perusahaan dapat digambarkan melalui analisis rasio keuangan ini. Analisis rasio keuangan bertujuan untuk membantu perusahaan dalam mengidentifisi kekuatan dan kelemahan keuangan suatu perusahaan, menilai kinerja laporan keuangan perusahaan dalam memberdayakan seluruh sumber daya yang ada untuk mencapai target yang ditetapkan perusahaan (Sujarweni, 2017 : 59).

\section{Financial Distress}

Financial distress adalah tahap penurunan dalam kondisi keuangan perusahaan yang terjadi sebelum terjadinya kebangkurutan ataupun likuidasi (Platt dan Platt, 2006). Ross et al. (2010 : 917) mengungkapkan financial distress sebagai situasi di mana arus kas operasi perusahaan tidak cukup untuk memenuhi kewajiban saat ini (seperti hutang atau beban bunga) dan perusahaan dipaksa untuk mengambil tindakan korektif. Dengan diketahuinya kondisi financial distress sejak dini, diharapkan perusahaan dapat melakukan tindakan-tindakan antisipasi agar perusahaan terhindar dari kebangkrutan (Almilia dan Kristijadi, 2003).

Tiga model penyebab terjadinya financial distress diungkapkan oleh Lizal (2002), yaitu :

1. Neoclassical model

Model ini menyatakan bahwa kebangkrutan adalah hal yang baik karena membebaskan sumber daya yang dialokasikan secara buruk.

2. Financial model
Kebangkrutan terjadi ketika perusahaan memiliki pengaturan aset yang tepat tetapi struktur keuangan tidak tepat.

3. Corporate governance model

Kebangkrutan terjadi ketika perusahaan memiliki pengaturan aset dan struktur keuangan yang tepat tetapi dikelola dengan buruk.

\section{Leverage}

Rasio leverage (rasio solvabilitas) merupakan rasio yang menggambarkan sejauh mana aktiva perusahaan dibiayai melalui hutang atau kemampuan perusahaan untuk membayar seluruh kewajibannya, baik kewajiban jangka pendek maupun kewajiban jangka panjang apabila perusahaan dibubarkan (dilikuidasi) (Kasmir, 2015 : 151). Perusahaan yang memiliki rasio leverage yang tinggi, akan memiliki risiko kerugian yang lebih besar. Pinjaman yang dimiliki perusahaan menentukan besar kecilnya rasio leverage. Oleh karena itu, manajer keuangan dituntut untuk mengelola rasio leverage dengan baik sehingga dapat menyeimbangkan pengembalian yang tinggi dengan tingkat risiko yang dihadapi (Kasmir, $2015: 152$ ).

\section{Pertumbuhan Perusahaan}

Rasio pertumbuhan menurut Kasmir (2015 : 114-115) merupakan rasio yang menggambarkan kemampuan perusahaan dalam mempertahankan posisi ekonominya di tengah pertumbuhan perekonomian dan sektor usaha. Setiap perusahaan memiliki tujuan utama untuk memperoleh laba dari hasil usahanya. Laba yang diperoleh perusahaan ini akan digunakan perusahaan semaksimal mungkin untuk kepentingan pemilik dan seluruh pihak yang terkait (shareholder).

\section{Good Corporate Governance}

Cadbury dalam Iskander dan Chamlou (2000) menjelaskan tata kelola perusahaan berkaitan untuk menjaga keseimbangan antara tujuan ekonomi, tujuan sosial, tujuan individu, dan tujuan komunitas. Tujuan tata kelola perusahaan adalah untuk mendorong penggunaan sumber daya secara efisien dan menyelaraskan kepentingan pribadi, perusahaan, dan 
masyarakat. Cadbury Committee (1992) mendefinisikan tata kelola perusahaan sebagai sistem yang berfungsi untuk mengarahkan dan mengendalikan perusahaan.

\section{Kepemilikan Manajerial}

Kepemilikan manajerial adalah kepemilikan saham yang dimiliki oleh pihak internal perusahaan yaitu manajemen. Kepemilikan saham oleh manajer dalam perusahaan mengakibatkan manajer memiliki fungsi ganda sebagai pemilik perusahaan sekaligus pengelola perusahaan. Semakin besar proporsi kepemilikan manajerial dalam suatu perusahaan, maka manajer akan memiliki tanggung jawab yang lebih besar dalam mengelola perusahaan (Triwahyuningtias dan Muharam, 2012). Hal tersebut dikarenakan manajer akan ikut merasakan manfaat dan risiko langsung dari setiap keputusan yang diambil.

\section{Kepemilikan Institusional}

Kepemilikan institusional akan mendorong pengawasan terhadap manajer agar manajer dapat mengelola kinerja perusahaan lebih optimal. Dengan adanya kepemilikan institusional, usaha monitoring yang dilakukan oleh kepemilikan institusional menjadi semakin efektif karena dapat mengendalikan perilaku oportunistik yang dilakukan oleh para manajer. Semakin tinggi tingkat kepemilikan institusional, semakin kuat monitoring yang dilakukan oleh pihak institusional terhadap perusahaan.

\section{Pengaruh Leverage terhadap Financial Distress}

Leverage merupakan pendanaan aktivitas operasi perusahaan melalui pihak ketiga dalam bentuk hutang. Leverage digunakan untuk mengukur sejauh mana pendanaan perusahaan dibiayai oleh hutang. Dalam melakukan aktivitasnya, perusahaan membutuhkan dana agar kegiatan operasional perusahaan dapat berjalan lancar. Dana tersebut dapat berupa hutang yang berasal dari kreditur. Perusahaan yang memiliki banyak kreditur akan semakin cepat bergerak ke arah financial distress dibanding perusahaan yang memiliki kreditur tunggal karena dengan banyaknya jumlah kreditur pada suatu perusahaan menunjukkan bahwa pembiayaan perusahaan lebih banyak menggunakan hutang sehingga dapat menimbulkan kesulitan pembayaran di masa yang akan datang. Kesulitan pembayaran ini disebabkan karena perusahaan harus menanggung pokok pinjaman ditambah bunga dari pinjaman tersebut untuk dibayarkan kepada kreditur.

Ha1 : Leverage cenderung berpengaruh positif terhadap financial distress.

\section{Pengaruh Pertumbuhan Perusahaan terhadap Financial Distress}

Pertumbuhan perusahaan menggambarkan kemampuan perusahaan dalam mempertahankan posisinya di dalam industri dan di tengah pertumbuhan ekonomi. Pertumbuhan perusahaan umumnya digambarkan melalui pertumbuhan penjualan. Pertumbuhan penjualan menggambarkan keberhasilan investasi yang dilakukan perusahaan pada periode lalu dan dapat dijadikan prediksi untuk pertumbuhan di masa yang akan datang. Hal tersebut menggambarkan keberhasilan manajemen dalam mengelola perusahaan jika penjualan dari satu periode ke periode berikutnya dapat meningkat. Semakin tinggi pertumbuhan penjualan suatu perusahaan menyebabkan laba yang diterima suatu perusahaan menjadi lebih tinggi. Pertumbuhan perusahaan yang semakin tinggi memungkinkan perusahaan untuk terhindar dari kesulitan keuangan.

Ha2 : Pertumbuhan perusahaan cenderung berpengaruh negatif terhadap financial distress.

\section{Pengaruh Leverage terhadap Financial Distress yang Dimoderasi oleh Kepemilikan Manajerial}

Perusahaan membutuhkan dana untuk membiayai aktivitasnya. Pendanaan yang didapat perusahaan biasanya berupa hutang dari pihak ketiga. Tingginya tingkat hutang yang dimiliki perusahaan akan menyebabkan biaya yang ditanggung perusahaan semakin tinggi dikarenakan perusahaan harus membayar pokok hutang ditambah bunga yang diakibatkan dari hutang tersebut. Hal ini akan menyebabkan perusahaan berpotensi mengalami kesulitan 
keuangan. Dengan adanya kepemilikan manajerial, diharapkan para manajer sebagai pemilik perusahaan sekaligus pengelola perusahaan akan bekerja lebih keras untuk kepentingan pemegang saham dimana manajer itu sendiri merupakan pemegang saham di dalamnya. Manajer diharapkan dapat mengelola perusahaan secara efisien sehinga perusahaan dapat memenuhi kewajiban-kewajibannya dan dapat menurunkan potensi kesulitan keuangan.

\section{Ha3 : Kepemilikan manajerial cenderung memperlemah pengaruh leverage terhadap financial distress.}

\section{Pengaruh Leverage terhadap Financial Distress yang Dimoderasi oleh Kepemilikan Institusional}

Pendanaan perusahaan dalam bentuk hutang akan menyebabkan perusahaan berpotensi mengalami kesulitan keuangan. Hal tersebut dikarenakan perusahaan mempunyai kewajiban dalam melunasi hutang tersebut. Dalam hal ini manajemen selaku pihak pengelola perusahaan harus berusaha untuk mengelola perusahaan agar dapat menciptakan kinerja yang efektif. Namun, dalam kenyataannya manajemen bertindak oportunistik untuk memaksimalkan kepentingan mereka. Dengan adanya kepemilikan institusional, investor institusional akan mendorong peningkatan pengawasan yang lebih optimal dan efektif terhadap kinerja manajemen dalam mengelola perusahaan agar hutang yang dimiliki perusahaan dapat diminimalisir sehingga perusahaan terhindar dari kesulitan keuangan.

Ha4 : Kepemilikan institusional cenderung memperlemah pengaruh leverage terhadap financial distress.

\section{Pengaruh Pertumbuhan Perusahaan terhadap Financial Distress yang Dimoderasi oleh Kepemilikan Manajerial}

Pertumbuhan perusahaan yang dinyatakan dalam pertumbuhan penjualan mencerminkan keberhasilan investasi pada periode lalu dan prediksi untuk pertumbuhan di masa yang akan datang. Semakin tinggi pertumbuhan suatu perusahaan menggambarkan bahwa perusahaan tersebut dapat mempertahankan posisinya dalam suatu industri dan di tengah pertumbuhan ekonomi. Hal ini menunjukkan bahwa perusahaan berhasil dalam menjalankan strategi pemasarannya sehingga potensi kesulitan keuangan dapat terhindar. Dengan adanya kepemilikan manajerial, dimana manajer memiliki dua peran sekaligus yaitu sebagai pemilik dan pengelola perusahaan akan mendorong manajer untuk bertindak secara hatihati dalam mengambil setiap keputusan yang berhubungan dengan perusahaan. Manajer memiliki tanggung jawab yang lebih besar dalam mengelola perusahaan serta mengambil keputusan untuk kesejahteraan perusahaan. Sebagai pengelola perusahaan, manajer berusaha untuk menghasilkan pendapatan yang lebih besar agar perusahaan terhindar dari ancaman kesulitan keuangan.

Ha5 : Kepemilikan manajerial cenderung memperkuat pengaruh pertumbuhan perusahaan terhadap financial distress.

\section{Pengaruh Pertumbuhan Perusahaan terhadap Financial Distress yang Dimoderasi oleh Kepemilikan Institusional}

Pertumbuhan perusahaan merupakan gambaran kemampuan perusahaan dalam meningkatkan penjualannya dari waktu ke waktu. Peningkatan penjualan yang ditandai dengan peningkatan pendapatan menunjukkan bahwa manajemen telah melakukan pengelolaan perusahaan dengan baik. Hal tersebut dapat menyebabkan perusahaan terhindar dari kesulitan keuangan. Dengan adanya investor institusional yang berpengalaman pada perolehan laba, investor institusional diyakini dapat membaca dan memprediksi perolehan laba di masa depan daripada investor perorangan. Hal tersebut dikarenakan investor institusional terdiri atas beberapa orang yang memberikan kesepakatan dalam pengambilan keputusan dan pengawasan terhadap manajer sehingga investor institusional tidak mudah diperdaya oleh manajemen. Tingginya kepemilikan institusional suatu perusahaan akan menyebabkan perusahaan terhindar dari kesulitan keuangan karena akan memonitoring kinerja manajemen dalam mengelola perusahaan terutama dalam pertumbuhan penjualan. 
Ha6 : Kepemilikan institusional cenderung memperkuat pengaruh pertumbuhan perusahaan terhadap financial distress.

\section{Metode Penelitian}

Obyek penelitian yang digunakan dalam penelitian ini adalah perusahaan manufaktur yang terdaftar di Bursa Efek Indonesia (BEI) periode 2015-2017. Adapun obyek yang akan diteliti adalah data laporan keuangan untuk periode 2015-2017 (web.idx.id). Penulis menggunakan perusahaan manufaktur sebagai obyek penelitian karena jumlah perusahaan manufaktur yang terdaftar di Bursa Efek Indonesia cukup banyak. Jumlah perusahaan manufaktur yang cukup banyak ini dapat menghindarkan penelitian dari kekurangan sampel setelah dilakukan penyesuaian kriteria pemilihan sampel.

\section{Variabel Penelitian}

\section{Financial Distess}

Financial distress merupakan kondisi perusahaan yang sedang mengalami kesulitan keuangan. Hal tersebut menunjukkan bahwa perusahaan berada dalam posisi tidak aman dan berpotensi mengalami kebangkrutan. Financial distress dalam penelitian ini yang dinyatakan dalam bentuk variabel dummy. Pengukuran tingkat kesulitan keuangan pada penelitian ini dengan menggunakan model Grover dan model Springate.

\section{Model Grover (FD_GROVER)}

Model Grover merupakan model turunan metode Altman yang dikembangkan oleh Jeffrey S. Grover pada tahun 2001. Model Grover dibentuk dengan melakukan penilaian ulang terhadap model Altman (Edi dan Tania, 2018). Rumus model Grover yang digunakan adalah :

$$
\begin{array}{rl}
\mathrm{G}=1.650 & \mathrm{X} 1+3.404 \mathrm{X} 2 \\
& -0.016 \text { ROA } \\
& +0.057
\end{array}
$$

Keterangan :

- G : 1 jika perusahaan terkena financial distress, 0 jika perusahaan tidak terkena financial

distress

- X1 : Working capital/Total assets
- X2 : Net profit before interest and tax/Total assets

- ROA: Net income to total assets (Return on Assets)

Kriteria penilaian metode Grover adalah sebagai berikut :

- Jika $\mathrm{G} \leq-0.02$, maka perusahaan dikategorikan dalam potensi bangkrut, dikategorikan angka 1.

- Jika $G \geq 0.01$, maka perusahaan dikategorikan dalam keadaan tidak bangkrut, dikategorikan angka 0 .

2. Model Springate (FD_SPRINGATE)

Model Springate dikembangkan oleh Gordon L.V. Springate pada tahun 1978 dengan menggunakan 40 sampel dan analisis multidiskriminan (Fatmawati, 2012). Springate melanjutkan studi Altman dan memilih empat rasio keuangan dalam menentukan apakah suatu perusahaan dalam kondisi sehat atau berpotensi mengalami bangkrut (Aminian, et al., 2016). Model ini menggunakan metode yang sama dengan Altman yaitu Multiple Discriminant Analysis (MDA) (Jayanti dan Rustiana, 2015). Rumus model Springate yang digunakan adalah:

$$
\begin{gathered}
\mathrm{S}=1.03 \mathrm{X} 1+3.07 \mathrm{X} 2+0.66 \mathrm{X} 3 \\
+0.4 \mathrm{X} 4
\end{gathered}
$$

Keterangan :

- X1 : Working capital/Total assets

- X2 : Net profit before interest and taxes/Total assets

- X3 : Net profit before taxes/Current liabilities

- X4 : Sales/Total assets

Kriteria penilaian model Springate adalah sebagai berikut :

- Jika $S<0.862$, maka perusahaan dikategorikan dalam potensi bangkrut, dikategorikan angka 1.

- Jika S > 0.862, maka perusahaan dikategorikan dalam keadaan tidak bangkrut, dikategorikan angka 0 .

\section{Leverage (LEV)}

Pengukuran leverage dalam penelitian ini menggunakan proksi Debt to Equity Ratio (DER) yang membandingkan total hutang yang dimiliki perusahaan baik hutang jangka panjang maupun 
hutang jangka pendek dengan total ekuitas perusahaan. Rasio ini berfungsi untuk mengetahui berapa bagian dari setiap rupiah modal yang dijadikan jaminan hutang. Berdasarkan penelitian yang dilakukan oleh Widati dan Pratama (2015), proksi pengukuran leverage sebagai berikut:

$$
\mathrm{DER}=\frac{\text { Total Hutang }}{\text { Total Modal }}
$$

\section{Pertumbuhan Perusahaan (GROWTH)}

Pertumbuhan perusahaan dalam penelitian ini menggunakan proksi pertumbuhan penjualan yang membandingkan selisih penjualan tahun sekarang dan penjualan tahun lalu dengan penjualan tahun lalu. Berdasarkan penelitian yang dilakukan oleh Eliu (2014), proksi pertumbuhan perusahaan sebagai berikut :

$$
\begin{aligned}
& \text { Sales Growth } \\
& =\frac{\operatorname{Net~Sales}_{(t)}-\operatorname{Net~Sales}_{(t-1)}}{\operatorname{Net~Sales}_{(t-1)}}
\end{aligned}
$$

\section{Kepemilikan Manajerial (KM)}

Kepemilikan manajerial merupakan kepemilikan saham yang dimiliki oleh manajemen perusahaan. Berdasarkan penelitian yang dilakukan oleh Yudadibrata dan Soenarno (2016), proksi kepemilikan manajerial adalah jumlah saham kepemilikan manajerial dibanding jumlah saham yang beredar.

\section{Kepemilikan Institusional (KI)}

Kepemilikan institusional merupakan proporsi saham biasa yang dimiliki pihak institusi. Berdasarkan penelitian yang dilakukan oleh Neldawati (2018), proksi kepemilikan institusional adalah jumlah saham institusional dari seluruh saham beredar.

\section{Teknik Pengumpulan Data}

Jenis data yang dikumpulkan dalam penelitian ini adalah data sekunder. Teknik pengumpulan data yang digunakan dalam penelitian ini adalah teknik observasi, yaitu dengan mengumpulkan dan mengkaji data sekunder yang dipublikasikan oleh Bursa Efek Indonesia. Penelitian ini menggunakan data sekunder berupa laporan keuangan tahunan perusahaan manufaktur yang terdaftar di Bursa Efek Indonesia periode 20152017 yang dapat diakses dari website Indonesian Stock Exchange (IDX) yaitu web.idx.id.

\section{Teknik Pengambilan Sampel}

Teknik pengambilan sampel dilakukan dengan nonprobability sampling dengan metode purposive sampling. Metode purposive sampling merupakan metode pengumpulan sampel yang didasarkan atas kriteria-kriteria tertentu (Cooper dan Schindler, 2014 : 359). Sampel yang dipilih adalah sampel yang dapat mewakili populasi dengan kriteria-kriteria sebagai berikut :

1. Perusahaan manufaktur yang terdaftar di Bursa Efek Indonesia periode 2015-2017 berdasarkan www.sahamok.com.

2. Perusahaan menerbitkan laporan keuangan tahunan per 31 Desember selama periode pengamatan (2015-2017) yang telah dipublikasikan melalui website Bursa Efek Indonesia yaitu web.idx.id.

3. Perusahaan tidak delisting selama tahun penelitian berlangsung.

4. Perusahaan yang tidak melakukan perpindahan sektor selama tahun penelitian berlangsung.

5. Perusahaan yang memiliki data lengkap setiap tahunnya sesuai yang dibutuhkan peneliti.

6. Perusahaan manufaktur yang menerbitkan laporan keuangan tahunan menggunakan mata uang rupiah.

\section{Teknik Analisis Data}

Dalam penelitian ini, Peneliti menggunakan teknik analisis data berupa analisis regresi logistik (logistic regression). Hal ini di karenakan variabel dependen yang digunakan dalam penelitian ini bersifat dikotomi (yang diberi kode 1 jika perusahaan mengalami kesulitan keuangan dan diberi kode 0 jika perusahaan tidak mengalami kesulitan keuangan).

Teknik analisis data yang digunakan dalam penelitian ini adalah :

\section{Statistik deskriptif}

Statistik deskriptif bertujuan untuk memberikan informasi berupa gambaran atau deskripsi suatu data yang dilihat dari nilai 
rata-rata (mean), standar deviasi, varian, maksimum dan minimum.

a. Rata-rata (Mean) berfungsi untuk mengetahui rata-rata tiap data kuantitatif yang diuji dalam penelitian ini.

b. Standar deviasi berfungsi untuk mengetahui seberapa besar penyimpangan yang dapat terjadi dari tiap-tiap variabel independen.

c. Nilai maksimum berfungsi untuk mengetahui berapa nilai tertinggi dari data penelitian.

d. Nilai Minimum berfungsi untuk mengetahui berapa nilai terendah dari data penelitian.

\section{Uji Kesamaan Koefisien}

Sebelum dilakukan pengujian lebih lanjut mengenai pengaruh variabel independen terhadap variabel dependen, maka perlu dilakukan uji kesamaan koefisien terlebih dahulu. Pengujian ini disebut dengan comparing two regression : the dummy variable approach. Hal ini dikarenakan data penelitian yang digunakan dalam penelitian ini adalah data penelitian yang menggabungkan data selama 3 tahun (cross sectional) dengan time series (pooling). Uji kesamaan koefisien dilakukan untuk mengetahui apakah pooling data penelitian (penggabungan data cross-sectional dengan time series) dapat dilakukan. Dalam penelitian ini mengambil periode 2015-2017 sehingga dummy 1 yaitu tahun 2015 dan dummy 2 yaitu tahun 2016. Bila signifikansi dummy tersebut diatas nilai $\alpha=5 \%$ maka tidak terdapat perbedaan koefisien dan terima $\mathrm{H}_{0}$, yang berarti pooling data dapat dilakukan sehingga pengujian data dapat dilakukan selama periode penelitian dalam satu kali uji.

\section{Menilai Keseluruhan Model (Overall Fit} Model)

Likelihood L dari model adalah probabililtas bahwa model yang dihipotesiskan menggambarkan data input. Penurunan likelihood (-2LogL) menunjukkan model regresi yang lebih baik atau dengan kata lain model yang dihipotesiskan fit dengan data (Ghozali, 2016 : 328).

Pengujian penelitian ini dilakukan dengan menggunakan tiga persamaan berdasarkan model Moderated Regression Analysis (MRA). Menurut Ghozali (2016 : 219), Moderated Regression Analysis (MRA) menggunakan pendekatan analitik yang mempertahankan integritas sampel dan memberikan dasar untuk mengontrol pengaruh variabel moderator. Untuk menggunakan MRA, maka harus membandingkan tiga persamaan regresi untuk menentukan jenis variabel moderator. Ketiga persamaan FD_GROVER :

$$
\begin{aligned}
& \operatorname{Ln} \frac{F D}{1-F D}=\mathrm{b}_{0}+\mathrm{b}_{1} \mathrm{LEV}+\mathrm{b}_{2} \text { GROWTH }+\varepsilon \\
& \operatorname{Ln} \frac{F D}{1-F D}=\mathrm{b}_{0}+\mathrm{b}_{1} \mathrm{LEV}+\mathrm{b}_{2} \mathrm{GROWTH}+\mathrm{b}_{3} \mathrm{KM}+\mathrm{b}_{4} \mathrm{KI}+\varepsilon \\
& \operatorname{Ln} \frac{F D}{1-F D}=\mathrm{b}_{0}+\mathrm{b}_{1} \mathrm{LEV}+\mathrm{b}_{2} \mathrm{GROWTH}+\mathrm{b}_{3} \mathrm{KM}+\mathrm{b}_{4} \mathrm{KI}+\mathrm{b}_{5} \text { LEV_KM }+\mathrm{b}_{6} \text { LEV_KI }+\mathrm{b}_{7} \text { GROWTH_KM } \\
& +b_{8} \text { GROWTH_KI }+\varepsilon \ldots \\
& \text { Ketiga persamaan FD_SPRINGATE : } \\
& \operatorname{Ln} \frac{F D}{1-F D}=\mathrm{b}_{0}+\mathrm{b}_{1} \mathrm{LEV}+\mathrm{b}_{2} \text { GROWTH }+\varepsilon \\
& \operatorname{Ln} \frac{F D}{1-F D}=\mathrm{b}_{0}+\mathrm{b}_{1} \mathrm{LEV}+\mathrm{b}_{2} \mathrm{GROWTH}+\mathrm{b}_{3} \mathrm{KM}+\mathrm{b}_{4} \mathrm{KI}+\varepsilon \\
& \operatorname{Ln} \frac{F D}{1-F D}=\mathrm{b}_{0}+\mathrm{b}_{1} \mathrm{LEV}+\mathrm{b}_{2} \mathrm{GROWTH}+\mathrm{b}_{3} \mathrm{KM}+\mathrm{b}_{4} \mathrm{KI}+\mathrm{b}_{5} \text { LEV_KM }+\mathrm{b}_{6} \text { LEV_KI }+\mathrm{b}_{7} \text { GROWTH_KM } \\
& +b_{8} \text { GROWTH_KI }+\varepsilon \text {. } \\
& \text { - } \quad \operatorname{Ln} \frac{\mathrm{FD}}{1-\mathrm{FD}} \\
& \text { - } b_{0} \\
& \text { - } b_{1}-b_{8} \\
& \text { - LEV } \\
& \text { - GROWTH }
\end{aligned}
$$




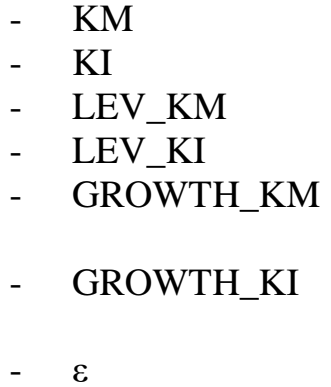

: Kepemilikan Manajerial

: Kepemilikan Institusional

: Leverage yang dimoderasi kepemilikan manajerial

: Leverage yang dimoderasi kepemilikan institusional

:Pertumbuhan perusahaan yang dimoderasi kepemilikan manajerial

:Pertumbuhan perusahaan yang dimoderasi kepemilikan institusional

\section{Koefisien Determinasi (Nagelkerke's $R$ Square)}

Nilai nagelkerke's $\mathrm{R}^{2} \quad$ dapat diinterpretasikan seperti nilai $\mathrm{R}^{2}$ pada multiple regression. Nilai yang mendekati satu berarti variabel-variabel independen mernberikan hampir semua informasi yang dibutuhkan untuk memprediksi variasi variabel dependen (Ghozali, 2016 : 329).

\section{Menguji Kelayakan Model Regresi}

Kelayakan model regresi dapat dilihat melalui tabel Hosmer and Lemeshow's Goodness of Fit Test. Jika Nilai Hosmer and Lemeshow's Goodness of Fit Test > 0.05, maka hipotesis nol tidak dapat ditolak dan berarti model mampu memprediksi nilai observasinya atau dapat dikatakan model dapat diterima karena cocok dengan data observasinya (Ghozal, 2016 : 329)

\section{Tabel Klasifikasi $2 \times 2$}

Tabel klasifikasi 2 x 2 digunakan untuk menghitung nilai estimasi yang benar (correct) dan salah (incorrect). Pada kolom merupakan dua nilai prediksi dari variabel dependen berupa perusahaan yang berpotensi financial distress dan perusahaan non financial distress, sedangkan pada baris menunjukkan nilai sesungguhnya dari variabel dependen perusahaan yang berpotensi financial distress dan perusahaan non financial distress (Ghozali, 2016 : 329).

Tabel 1

Jenis-Jenis Variabel Moderator

\begin{tabular}{|c|c|c|}
\hline & $\begin{array}{c}\text { Berhubungan dengan kriterion } \\
\text { dan atau prediktor }\end{array}$ & $\begin{array}{c}\text { Tidak berhubungan dengan } \\
\text { kriterion dan prediktor }\end{array}$ \\
\hline $\begin{array}{c}\text { Tidak berinteraksi dengan } \\
\text { predictor }\end{array}$ & $\begin{array}{c}\mathbf{1} \\
\text { Intervening, Exogen, } \\
\text { Antesedent, Prediktor }\end{array}$ & $\begin{array}{c}\mathbf{2} \\
\text { Moderator } \\
\text { (Homologizer) }\end{array}$ \\
\hline Berinteraksi dengan predictor & $\begin{array}{c}\mathbf{3} \\
\text { Moderator } \\
\text { (Quasi Moderator) }\end{array}$ & $\begin{array}{c}\text { Moderator } \\
\text { (Pure Moderator) }\end{array}$ \\
\hline
\end{tabular}

Sumber : Buku Ghozali (2016 : 214)

\section{Pengujian Variabel Moderator}

Variabel moderator atau variabel spesifikasi adalah variabel yang menspesifikasikan bentuk dan atau besarnya hubungan antara predictor (variabel independen) dan criteria (variabel dependen) (Ghozali, 2016 : 213214). Jenis-jenis variabel moderator menurut Sharma et al. dalam Ghozali (2016 : 214) disajikan dalam table 1 di atas.

Keterangan tabel :

1. Kuadran 1, jika variabel moderator $(Z)$ berhubungan dengan kriterion (Y) dan atau prediktor $(\mathrm{X})$, tetapi variabel moderator $(Z)$ tidak berinteraksi dengan prediktor $(\mathrm{X})$, maka variabel $\mathrm{Z}$ bukanlah moderator tetapi merupakan variabel intervening, exogen, antesendent, dan prediktor (independen).

2. Kuadran 2, jika variabel moderator $(\mathrm{Z})$ mempengaruhi kekuatan hubungan, tetapi tidak berinteraksi dengan variabel prediktor (X) dan tidak berhubungan secara signifikan baik dengan prediktor (X) maupun dengan kriterion (Y). 
3. Kuadran 3, jika variabel moderator $(\mathrm{Z})$ berhubungan dengan variabel kriterion (Y) dan atau variabel prediktor (X) serta berinteraksi dengan variabel prediktor (X).

4. Kuadran 4, jika variabel moderator $(Z)$ tidak berhubungan dengan kriterion $(\mathrm{Y})$ dan prediktor $(\mathrm{X})$, tetapi berinteraksi dengan variabel prediktor (X) menghasilkan output yang memiliki pengaruh signifikan.

\section{Hasil Dan Pembahasan}

\section{Uji Statistik Deskriptif}

Berdasarkan lampiran 1, diketahui informasi bahwa financial distress dengan proksi Grover memiliki nilai rata-rata sebesar 0.05 dan nilai standar deviasi sebesar 0.213. Hal ini menunjukkan bahwa nilai standar deviasi lebih tinggi dibanding nilai rata-rata yang berarti sebaran data untuk variabel financial distress dengan proksi Grover cenderung di bawah ratarata. Dengan tingginya nilai standar deviasi pada variabel financial distress proksi Grover menjelaskan bahwa perusahaan yang mengalami kesulitan keuangan pada sampel perusahaan yang digunakan cenderung sedikit. Sampel perusahaan yang tidak mengalami kesulitan keuangan sebanyak 200 perusahaan. Sedangkan, sampel perusahaan yang mengalami kesulitan keuangan sebanyak 10 perusahaan. Artinya, perusahaan yang tidak mengalami kesulitan keuangan lebih banyak dibanding perusahaan yang mengalami kesulitan keuangan.

Financial distress dengan proksi Springate memiliki nilai rata-rata sebesar 0.43 dan nilai standar deviasi sebesar 0.496. Hal ini menunjukkan bahwa nilai standar deviasi lebih tinggi dibanding nilai rata-rata yang berarti sebaran data untuk variabel financial distress dengan proksi Springate cenderung dibawah ratarata. Dengan tingginya nilai standar deviasi pada variabel financial distress proksi Springate menjelaskan bahwa perusahaan yang mengalami kesulitan keuangan pada sampel perusahaan yang digunakan cenderung lebih sedikit. sampel perusahaan yang tidak mengalami kesulitan keuangan sebanyak 120 sampel data perusahaan. Sedangkan, sampel perusahaan yang mengalami kesulitan keuangan sebanyak 90 sampel data perusahaan. Artinya, perusahaan yang tidak mengalami kesulitan keuangan lebih banyak dibanding perusahaan yang mengalami kesulitan keuangan.

Variabel leverage (LEV) memiliki nilai ratarata sebesar 0.987 dan nilai standar deviasi sebesar 0.853 . Hal ini menunjukkan bahwa nilai rata-rata lebih tinggi dibanding nilai standar deviasi yang berarti sebaran data untuk variabel leverage cenderung ke rata-rata. Dengan tingginya nilai rata-rata pada variabel leverage menjelaskan bahwa kemampuan perusahaan dalam melunasi kewajibannya masih rendah. Nilai tertinggi leverage sebesar 4.870 diperoleh PT. Saranacentral Bajatama Tbk (BAJA) pada tahun 2015 dan nilai terendah leverage sebesar 0.076 diperoleh PT. Industri Jamu dan Farmasi Sido Muncul Tbk (SIDO) pada tahun 2015.

Variabel pertumbuhan perusahaan (GROWTH) memiliki nilai rata-rata sebesar 0.031 dan nilai standar deviasi sebesar 0.137 . Hal ini menunjukkan bahwa nilai standar deviasi lebih tinggi dibanding nilai rata-rata yang berarti sebaran data untuk variabel pertumbuhan perusahaan cenderung di bawah rata-rata. Dengan tingginya nilai standar deviasi pada variabel pertumbuhan perusahaan menjelaskan bahwa pertumbuhan perusahaan masih tergolong rendah. Nilai tertinggi pertumbuhan perusahaan sebesar 0.540 diperoleh PT. Wijaya Karya Beton Tbk (WTON) pada tahun 2017 dan nilai terendah pertumbuhan perusahaan sebesar -0.500 diperoleh PT. Star Petrochem Tbk (STAR) pada tahun 2016.

Variabel kepemilikan manajerial (KM) memiliki nilai rata-rata sebesar 0.054 dan nilai standar deviasi sebesar 0.127. Hal ini menunjukkan bahwa nilai standar deviasi lebih tinggi dibanding nilai rata-rata yang berarti sebaran data untuk variabel kepemilikan manajerial cenderung di bawah rata-rata. Dengan tingginya nilai standar deviasi pada variabel kepemilikan manajerial menjelaskan bahwa kepemilikan manajerial dalam suatu perusahaan masih tergolong rendah. Nilai tertinggi kepemilikan manajerial sebesar 0.739 diperoleh PT. Saranacentral Bajatama Tbk (BAJA) pada tahun 2015-2017 dan nilai terendah kepemilikan 
manajerial sebesar 0.000 diperoleh 90 perusahaan selama periode 2015-2017.

Variabel kepemilikan institusional (KI) memiliki nilai rata-rata sebesar 0.668 dan nilai standar deviasi sebesar 0.217. Hal ini menunjukkan bahwa nilai rata-rata lebih tinggi dibanding nilai standar deviasi yang berarti sebaran data untuk variabel kepemilikan institusional cenderung ke rata-rata. Dengan tingginya nilai rata-rata pada variabel kepemilikan institusional menjelaskan bahwa perusahaan sampel yang memiliki kepemilikan institusional cenderung tinggi. Nilai tertinggi kepemilikan institusional sebesar 0.994 diperoleh PT. Tunas Alfin Tbk (TALF) pada tahun 2017 dan nilai terendah kepemilikan institusional sebesar 0.000 diperoleh PT. Saranacentral Bajatama Tbk (BAJA) pada tahun 2015-2017 dan PT. Industri Jamu dan Farmasi Sido Muncul Tbk (SIDO) pada tahun 2015 dan 2016.

\section{Uji Kesamaan Koefisien (Uji pooling)}

Dari lampiran 2, nilai sig $>0.05$ sehingga dapat disimpulkan bahwa tidak terdapat perbedaan koefisien dan data lolos uji pooling.

\section{Menilai Keseluruhan Model (Overall Model Fit)}

Dari lampiran 3, pada model 1, nilai -2LogL FD_GROVER dan FD_SPRINGATE awal adalah sebesar 80.407 dan 286.821. Namun, setelah dimasukkan penambahan variabel independen berupa variabel leverage dan pertumbuhan perusahaan, nilai -2LogL FD_GROVER dan FD_SPRINGATE akhir mengalami penurunan menjadi 65.382 dan 232.802

Pada model 2, nilai -2LogL FD_GROVER dan FD_SPRINGATE awal adalah sebesar 80.407 dan 286.821. Namun, setelah dimasukkan penambahan variabel independen berupa variabel leverage, pertumbuhan perusahaan, kepemilikan manajerial, dan kepemilikan institusional, nilai 2LogL FD_GROVER dan FD_SPRINGATE akhir mengalami penurunan menjadi 65.104 dan 229.069.

Pada model 3, nilai -2LogL FD_GROVER dan FD_SPRINGATE awal adalah sebesar 80.407 dan 286.821. Namun, setelah dimasukkan penambahan variabel independen berupa variabel leverage, pertumbuhan perusahaan, kepemilikan manajerial, kepemilikan institusional, interaksi leverage dan kepemilikan manajerial, interaksi leverage dan kepemilikan institusional, interaksi pertumbuhan perusahaan dan kepemilikan manajerial, serta interaksi pertumbuhan perusahaan dan kepemilikan institusional, nilai 2LogL FD_GROVER dan FD_SPRINGATE akhir mengalami penurunan menjadi 58.687 dan 202.121.

Berdasarkan penilaian -2LogL baik pada model Grover maupun model Springate mengalami penurunan pada setiap modelnya (model 1-3), sehingga dapat disimpulkan bahwa penambahan variabel independen yang dilakukan pada setiap model dapat memperbaiki model fit.

\section{Koefisien Determinasi (Nagelkerke's $R$ Square)}

Dari lampiran 3, dapat dilihat bahwa pada model 1, nilai Nagelkerke $R$ Square model Grover adalah 0.217 sedangkan nilai Nagelkerke $R$ Square model Springate adalah 0.305. Hal ini menunjukkan bahwa variabel dependen (financial distress) dapat dipengaruhi oleh variabel independen (leverage dan pertumbuhan perusahaan) sebesar 21.7\% untuk model Grover dan $30.5 \%$ untuk model Springate. Sisanya sebesar $78.3 \%$ pada model Grover dan $69.5 \%$ pada model Springate dipengaruhi oleh variabelvariabel lain di luar model.

Pada model 2, nilai Nagelkerke $R$ Square model Grover adalah 0.221 sedangkan nilai Nagelkerke $R$ Square model Springate adalah 0.323 . Hal ini menunjukkan bahwa variabel dependen (financial distress) dapat dipengaruhi oleh variabel independen (leverage, pertumbuhan perusahaan, kepemilikan manajerial, dan kepemilikan institusional) sebesar $22.1 \%$ untuk model Grover dan 32.3\% untuk model Springate. Sisanya sebesar $77.9 \%$ untuk model Grover dan $67.7 \%$ untuk model Springate dipengaruhi oleh variabel-variabel lain di luar model.

Pada model 3, nilai Nagelkerke $R$ Square pada model Grover adalah 0.309 sedangkan nilai Nagelkerke $R$ Square model Springate adalah 0.446. Hal ini menunjukkan bahwa variabel dependen (kesulitan keuangan yang dialami suatu perusahaan/financial distress) dapat dipengaruhi oleh variabel independen (leverage, pertumbuhan 
perusahaan, kepemilikan manajerial, kepemilikan institusional, interaksi leverage dan kepemilikan manajerial, interaksi leverage dan kepemilikan institusional, interaksi pertumbuhan perusahaan dan kepemilikan manajerial, serta interaksi pertumbuhan perusahaan dan kepemilikan institusional) sebesar $30.9 \%$ untuk model Grover dan $44.6 \%$ untuk model Springate. Sisanya sebesar $69.1 \%$ untuk model Grover dan $55.4 \%$ untuk model Springate dipengaruhi oleh variabel-variabel lain di luar model.

Berdasarkan hasil pengujian model Grover maupun model Springate pada model pertama, kedua, dan ketiga pada lampiran 3 dapat dilihat bahwa terjadi kenaikan nilai Nagelkerke $R$ Square dari model satu hingga model tiga.

\section{Menguji Kelayakan Model Regresi}

Kelayakan model regresi dapat dinilai dengan menggunakan Hosmer and Lemeshow Goodness of Fit Test pada lampiran 3. Pada model 1, nilai signifikansi pada goodness of fit test untuk model Grover sebesar 0.916 sedangkan nilai signifikansi untuk model Springate sebesar 0.233. Pada model 2, nilai signifikansi pada goodness of fit test untuk model Grover sebesar 0.363 sedangkan nilai signifikansi untuk model Springate sebesar 0.500. Pada model 3, nilai signifikansi pada goodness of fit test untuk model Grover sebesar 0.942 sedangkan nilai signifikansi untuk model Springate sebesar 0.687.

Berdasarkan hasil pengujian model pertama, kedua, dan ketiga pada model regresi logistik yang digunakan dalam penelitian ini menunjukkan bahwa nilai signifikansi untuk ketiga model tersebut baik dengan model Grover maupun model Springate memiliki nilai signifikansi diatas 0.05 . Hal ini menunjukkan bahwa model regresi logistik mampu memprediksi nilai observasinya karena sesuai dengan data observasinya.

\section{Tabel Klasifikasi 2 × 2}

Tabel klasifikasi 2 x 2 pada lampiran 3 dapat digunkan untuk menunjukkan kekuatan prediksi dari model regresi FD_GROVER dan FD_SPRINGATE untuk memprediksi kemungkinan perusahaan mengalami kesulitan keuangan.
Pada model 1, kekuatan prediksi untuk memprediksi kemungkinan perusahaan yang mengalami kesulitan keuangan, yaitu sebesar $10.0 \%$ ( 1 perusahaan dari 10 perusahaan yang diprediksi mengalami kesulitan keuangan) untuk model Grover, sedangkan sebanyak 57.8\% (52 perusahaan dari 90 perusahaan yang diprediksi mengalami kesulitan keuangan) untuk model Springate. Kekuatan prediksi untuk memprediksi kemungkinan perusahaan yang tidak mengalami kesulitan keuangan sebesar 99.0\% (198 perusahaan dari 200 perusahaan yang diprediksi tidak mengalami kesulitan keuangan) untuk model Grover dan sebesar 84.2\% (101 perusahaan dari 120 perusahaan yang diprediksi tidak mengalami kesulitan keuangan) untuk model Springate. Ketepatan klasifikasi secara keseluruhan sebesar $94.8 \%$ untuk model Grover dan $72.9 \%$ untuk model Springate.

Pada model 2, kekuatan prediksi untuk memprediksi kemungkinan perusahaan yang mengalami kesulitan keuangan, yaitu sebesar $10.0 \%$ (1 perusahaan dari 10 perusahaan yang diprediksi mengalami kesulitan keuangan) untuk model Grover, sedangkan sebanyak 58.9\% (53 perusahaan dari 90 perusahaan yang diprediksi mengalami kesulitan keuangan) untuk model Springate. Kekuatan prediksi untuk memprediksi kemungkinan perusahaan yang tidak mengalami kesulitan keuangan sebesar 99.0\% (198 perusahaan dari 200 perusahaan yang diprediksi tidak mengalami kesulitan keuangan) untuk model Grover dan sebesar $85.8 \% \quad(103$ perusahaan dari 120 perusahaan yang diprediksi tidak mengalami kesulitan keuangan) untuk model Springate. Ketepatan klasifikasi secara keseluruhan sebesar $94.8 \%$ untuk model Grover dan $74.3 \%$ untuk model Springate.

Pada model 3, kekuatan prediksi untuk memprediksi kemungkinan perusahaan yang mengalami kesulitan keuangan, yaitu sebesar $20.0 \%$ (2 perusahaan dari 10 perusahaan yang diprediksi mengalami kesulitan keuangan) untuk model Grover, sedangkan sebanyak $61.1 \%$ (55 perusahaan dari 90 perusahaan yang diprediksi mengalami kesulitan keuangan) untuk model Springate. Kekuatan prediksi untuk memprediksi kemungkinan perusahaan yang tidak mengalami kesulitan keuangan sebesar $100.0 \%$ (200 perusahaan dari 200 perusahaan yang diprediksi 
tidak mengalami kesulitan keuangan) untuk model Grover dan sebesar 85.8\% (103 perusahaan dari 120 perusahaan yang diprediksi tidak mengalami kesulitan keuangan) untuk model Springate. Ketepatan klasifikasi secara keseluruhan sebesar 96.2\% untuk model Grover dan $75.2 \%$ untuk model Springate.

\section{Model Regresi Logistik yang Terbentuk}

Model regresi logistik yang terbentuk dapat dilihat pada lampiran 3. Hasil penelitian selama 3 tahun periode sebagai berikut :

\section{Model Grover}

a. Variabel leverage (LEV) pada model 1 memiliki nilai B sebesar 1.029 dan nilai signifikansi sebesar $(0.000 / 2) 0.000<\alpha$ (0.05) yang menunjukkan bahwa leverage cenderung berpengaruh positif secara signifikan terhadap financial distress.

b. Variabel pertumbuhan perusahaan (GROWTH) pada model 1 memiliki nilai B sebesar -2.909 dan nilai signifikansi sebesar (0.198/2) $0.099>\alpha(0.05)$ yang menunjukkan bahwa pertumbuhan perusahaan tidak berpengaruh terhadap financial distress.

c. Pengaruh kepemilikan manajerial dalam memoderasi hubungan leverage terhadap financial distress pada model 3 memiliki nilai $\mathrm{B}$ sebesar 4.322 dan nilai signifikansi sebesar (0.453/2) $0.227>\alpha$ (0.05), yang menunjukkan bahwa interaksi leverage dan kepemilikan manajerial (LEV_KM) tidak berpengaruh terhadap financial distress. kepemilikan manajerial merupakan homologizer moderator.

d. Pengaruh kepemilikan institusional dalam memoderasi hubungan leverage terhadap financial distress pada model 3 memiliki nilai B sebesar -0.027 dan nilai signifikansi sebesar (0.993/2) $0.497>\alpha$ (0.05), yang menunjukkan bahwa interaksi leverage dan kepemilikan institusional (LEV_KI) tidak berpengaruh terhadap financial distress. kepemilikan institusional merupakan homologizer moderator. e. Pengaruh kepemilikan manajerial dalam memoderasi hubungan pertumbuhan perusahaan terhadap financial distress pada model 3 memiliki nilai B sebesar 30.517 dan nilai signifikansi sebesar $(0.500 / 2) \quad 0.250>\alpha \quad(0.05)$, yang menunjukkan bahwa interaksi pertumbuhan perusahaan dan kepemilikan manajerial (GROWTH_KM) tidak berpengaruh terhadap financial distress. Kepemilikan manajerial merupakan homologizer moderator.

f. Pengaruh kepemilikan institusional dalam memoderasi hubungan pertumbuhan perusahaan terhadap financial distress pada model 3 memiliki nilai B sebesar -0.910 dan nilai signifikansi sebesar (0.954/2) $0.477>\alpha$ (0.05), yang menunjukkan bahwa interaksi pertumbuhan perusahaan dan kepemilikan institusional (GROWTH_KI) tidak berpengaruh terhadap financial distress. Kepemilikan institusional merupakan homologizer moderator.

\section{Model Springate}

a. Variabel leverage (LEV) pada model 1 memiliki nilai B sebesar 1.496 dan nilai signifikansi sebesar $(0.000 / 2) 0.000<\alpha$ (0.05) yang menunjukkan bahwa leverage cenderung berpengaruh positif secara signifikan terhadap financial distress.

b. Variabel pertumbuhan perusahaan (GROWTH) pada model 1 memiliki nilai B sebesar -4.444 dan nilai signifikansi sebesar $(0.001 / 2) 0.0005<\alpha(0.05)$ yang menunjukkan bahwa pertumbuhan perusahaan cenderung berpengaruh negatif secara signifikan terhadap financial distress.

c. Pengaruh kepemilikan manajerial dalam memoderasi hubungan leverage terhadap financial distress pada model 3 memiliki nilai B sebesar 24.653 dan nilai signifikansi sebesar (0.120/2) $0.060>\alpha$ (0.05), yang menunjukkan bahwa interaksi leverage dan kepemilikan manajerial (LEV_KM) tidak 
berpengaruh terhadap financial distress. Kepemilikan manajerial merupakan predictor moderator

d. Pengaruh kepemilikan institusional dalam memoderasi hubungan leverage terhadap financial distress pada model 3 memiliki nilai B sebesar -6.902 dan nilai signifikansi sebesar $(0.006 / 2) 0.003<\alpha$ (0.05), yang menunjukkan bahwa kepemilikan institusional cenderung memperlemah pengaruh positif antara leverage terhadap financial distress. Kepemilikan institusional merupakan pure moderator.

e. Pengaruh kepemilikan manajerial dalam memoderasi hubungan pertumbuhan perusahaan terhadap financial distress pada model 3 memiliki nilai B sebesar 59.160 dan nilai signifikansi sebesar $(0.174 / 2) \quad 0.087>\alpha \quad(0.05)$, yang menunjukkan bahwa interaksi pertumbuhan perusahaan dan kepemilikan manajerial (GROWTH_KM) tidak berpengaruh terhadap financial distress. Kepemilikan manajerial merupakan predictor moderator.

f. Pengaruh kepemilikan institusional dalam memoderasi hubungan pertumbuhan perusahaan terhadap financial distress pada model 3 memiliki nilai $B$ sebesar 3.423 dan nilai signifikansi sebesar $(0.772 / 2) 0.386>\alpha$ (0.05), yang menunjukkan bahwa interaksi pertumbuhan perusahaan dan kepemilikan institusional (GROWTH_KI) tidak berpengaruh terhadap financial distress. Kepemilikan institusional merupakan homologizer moderator.

\section{Pembahasan}

\section{Pengaruh Leverage terhadap Financial Distress}

Berdasarkan hasil uji, didapat hasil bahwa leverage cenderung berpengaruh positif dan signifikan terhadap financial distress baik dengan model Grover maupun model Springate sehingga
$\mathrm{H}_{0}$ ditolak dan $\mathrm{H}_{\mathrm{a} 1}$ diterima. Hal ini menunjukkan bahwa perusahaan menggunakan modal yang dimilikinya sebagai jaminan untuk melunasi kewajiban dalam menjalankan kegiatan usahanya. Jumlah hutang yang semakin tinggi dibanding total ekuitas yang dimiliki perusahaan akan menyebabkan perusahaan mengalami kesulitan dalam melakukan pembayaran hutang dan beban bunga. Kesulitan pembayaran tersebut akan menyebabkan perusahaan memiliki beban yang semakin besar sehingga potensi perusahaan untuk mengalami financial distress semakin besar. Berdasarkan teori agensi, tingginya leverage suatu perusahaan menandakan bahwa keputusan yang diambil pihak manajemen dalam mengelola perusahaan dengan menggunakan hutang dari pihak ketiga merupakan keputusan yang tidak tepat. Tingginya leverage yang terdapat dalam suatu perusahaan menandakan bahwa manajemen selaku pihak agen tidak mampu memaksimalkan kepentingan pemegang saham selaku prinsipal. Hal ini dikarenakan perusahaan memiliki tingkat hutang yang tinggi sehingga perusahaan harus melunasi pokok pinjaman beserta bunga atas pinjaman tersebut.

\section{Pengaruh Pertumbuhan Perusahaan terhadap Financial Distress}

Berdasarkan hasil uji, dapat dilihat bahwa pertumbuhan perusahaan tidak berpengaruh terhadap financial distress dengan model Grover sehingga $\mathrm{H}_{0}$ diterima dan $\mathrm{H}_{\mathrm{a} 2}$ ditolak. Hal ini menunjukkan bahwa penjualan tidak menjadi acuan utama untuk mengukur financial distress. Penjualan yang mengalami penurunan belum tentu menyebabkan perusahaan mengalami kesulitan keuangan. Pada umumnya, penurunan penjualan mengurangi laba yang diperoleh suatu perusahaan. Namun, penurunan penjualan yang dialami suatu perusahaan tidak secara langsung membuat perusahaan mengalami kerugian, penurunan penjualan tersebut hanya mengurangi laba yang diperoleh perusahaan. Selama penurunan penjualan tersebut tidak melampaui suatu batas, maka penurunan tersebut dianggap tidak bermasalah.

Berdasarkan hasil uji, dapat dilihat bahwa pertumbuhan perusahaan cenderung berpengaruh negatif terhadap financial distress dengan model Springate sehingga $\mathrm{H}_{0}$ ditolak dan $\mathrm{H}_{\mathrm{a}}$ diterima. Hal ini menunjukkan bahwa perusahaan yang 
mempunyai pertumbuhan penjualan yang positif mengindikasikan bahwa perusahaan tersebut dapat mempertahankan posisi ekonomi dan kelangsungan hidupnya. Semakin tinggi pertumbuhan penjualan yang dialami oleh suatu perusahaan menyebabkan laba yang diterima suatu perusahaan semakin tinggi. Pertumbuhan penjualan yang dialami perusahaan menandakan bahwa perusahaan tersebut berhasil menjalankan strateginya dalam hal pemasaran dan penjualan produk sehingga memberikan tanda bahwa perusahaan tersebut sedang mengalami perkembangan sehingga potensi terjadinya financial distress dapat berkurang.

Berdasarkan teori agensi, manajemen selaku agen yang melakukan pengelolaan terhadap perusahaan harus melaksanakan kegiatan operasional sesuai dengan kontrak yang ada untuk menyejahterakan pemegang saham selaku prinsipal. Pertumbuhan penjualan yang mengalami peningkatan mengindikasikan bahwa manajemen telah mengelola perusahaan dengan maksimal. Keputusan yang diambil manajemen dalam mengelola perusahaan telah dilakukan secara hati-hati agar tidak menimbulkan kesalahan atau kerugian.

\section{Pengaruh Leverage terhadap Financial Distress yang Dimoderasi oleh Kepemilikan Manajerial}

Berdasarkan hasil uji, dapat dilihat bahwa kepemilikan manajerial tidak terbukti berpengaruh dalam memperlemah pengaruh positif antara leverage terhadap financial distress baik dengan model Grover maupun model Springate sehingga $\mathrm{H}_{0}$ diterima dan $\mathrm{H}_{23}$ ditolak. Hal tersebut dikarenakan manajer tidak mengelola perusahaan secara efisien sehingga perusahaan tetap memiliki tingkat hutang yang tinggi. Hutang yang tinggi akan menyebabkan perusahaan tidak dapat melunasi jumlah kewajiban yang dimilikinya. Selain itu, dalam melakukan kegiatan operasional perusahaan, manajer sering kali bertentangan dengan keinginan para pemegang saham. Manajer berusaha untuk mementingkan kesejahteraannya sendiri sehingga tidak menciptakan kinerja yang efisien dalam melunasi kewajiban yang dimiliki perusahaan. Tingginya hutang yang dimiliki perusahaan dapat menyebabkan perusahaan berpotensi mengalami financial distress. Hasil penelitian ini tidak mendukung teori agensi yang menyatakan konflik keagenan yang muncul antara prinsipal dan agen dapat diatasi dengan mengeluarkan biaya keagenan berupa insentif tambahan bagi manajemen berupa proporsi saham. Adanya proporsi saham yang dimiliki oleh pihak manajemen diharapkan dapat meningkatkan tanggung jawab manajemen dalam menjalankan kegiatan operasional perusahaan dan berusaha mengambil setiap keputusan secara hati-hati demi kesejahteraan perusahaan.

\section{Pengaruh Leverage terhadap Financial Distress yang Dimoderasi oleh Kepemilikan Institusional}

Berdasarkan hasil uji, dapat dilihat bahwa kepemilikan institusional tidak terbukti berpengaruh dalam memperlemah pengaruh positif antara leverage terhadap financial distress dengan model Grover sehingga $\mathrm{H}_{0}$ diterima dan $\mathrm{H}_{\mathrm{a} 4}$ ditolak. Hal ini menunjukkan Kepemilikan saham oleh pihak institusi yang seharusnya digunakan untuk mendorong aktivitas monitoring manajemen tidak dilakukan dengan baik oleh pihak institusi. Investor institusi terkadang tidak melakukan fungsi pengawasan sebagaimana mestinya sehingga memperlemah pengawasan terhadap manajemen. Dengan lemahnya pengawasan terhadap manajemen selaku pihak pengelola perusahaan akan menyebabkan manajemen menjadi leluasa untuk melakukan tindakan yang menguntungkan manajemen itu sendiri sehingga manajemen tidak melakukan pengelolaan perusahaan dengan baik. Lemahnya pengelolaan manajemen terhadap hutang perusahaan akan menyebabkan perusahaan cenderung menggunakan hutang kembali untuk menutupi hutang yang ada. Hal tersebut akan menyebabkan tingkat hutang perusahaan bertambah dan berpotensi mengalami kesulitan keuangan.

Berdasarkan hasil uji, dapat dilihat bahwa kepemilikan institusional cenderung memperlemah pengaruh positif antara leverage terhadap financial distress dengan model Springate sehingga $\mathrm{H}_{0}$ ditolak dan $\mathrm{H}_{\mathrm{a} 4}$ diterima. Hal ini menunjukkan bahwa tinginya kepemilikan saham oleh investor institusional akan meningkatkan aktivitas monitoring terhadap 
manajemen sehingga potensi manajemen untuk melakukan tindakan yang menguntungkan dirinya sendiri dapat ditekan. Kepemilikan saham dengan institusi yang beragam akan menjadikan pengawasan yang dilakukan investor institusional lebih kuat sehingga dapat menekan manajemen untuk bertindak secara profesional dan optimal dalam menetapkan kebijakan untuk meningkatkan keuntungan. Keuntungan tersebut dapat digunakan untuk membayar sejumlah kewajiban yang dimiliki perusahaan. Dengan tingginya keuntungan yang diperoleh perusahaan akan meminimalkan biaya yang dimiliki perusahaan untuk membayar hutang dan bunga sehingga potensi terjadinya kesulitan keuangan akan berkurang.

Berdasarkan teori agensi, pengawasan dari pihak luar seperti institusi dibutuhkan untuk mengawasi manajemen dalam melakukan kegiatan operasional.

Adanya kepemilikan saham oleh pihak institusi akan membantu prinsipal dalam melakukan pengawasan terhadap kinerja manajemen. Semakin besar proporsi saham yang dimiliki pihak institusi maka pengawasan terhadap manajemen yang dilakukan oleh pihak institusi akan semakin ketat. Hal tersebut akan menyebabkan manajemen menjadi berhati-hati dalam mengambil setiap keputusan bagi perusahaan agar kesulitan keuangan dapat terhindar.

\section{Pengaruh Pertumbuhan Perusahaan terhadap Financial Distress yang Dimoderasi oleh Kepemilikan Manajerial}

Berdasarkan hasil uji, dapat dilihat bahwa kepemilikan manajerial tidak terbukti berpengaruh dalam memperkuat pengaruh negatif antara pertumbuhan perusahaan terhadap financial distress baik dengan model Grover maupun model Springate sehingga $\mathrm{H}_{0}$ diterima dan $\mathrm{H}_{\mathrm{a} 5}$ ditolak. Dalam melakukan kegiatan operasional perusahaan, para pemegang saham mempercayakan pengelolaan perusahaan kepada para manajer dan diharapkan manajer akan mampu memaksimalkan laba melalui pertumbuhan penjualan. Namun, dalam mengelola perusahaan, manajer seringkali bertentangan dengan keinginan pemegang saham. Manajer berusaha untuk meningkatkan kesejahteraannya sendiri sehingga tidak memaksimalkan pengelolaan perusahaan. Pengelolaan yang buruk menyebabkan pendapatan yang dihasilkan perusahaan tidak maksimal bahkan mengalami penurunan sehingga menyebabkan perusahaan berpotensi mengalami financial distress. Hasil penelitian ini tidak sesuai dengan teori agensi yang menyatakan bahwa dengan adanya kepemilikan manajerial dalam suatu perusahaan akan menyelaraskan potensi perbedaan kepentingan antara pemegang saham di luar manajemen. Hal tersebut mengartikan bahwa semakin tinggi proporsi kepemilikan saham yang dimiliki oleh direksi, maka akan menunjukkan kinerja suatu perusahaan yang semakin baik sehingga kecil kemungkinan perusahaan mengalami kesulitan keuangan.

\section{Pengaruh Pertumbuhan Perusahaan terhadap Financial Distress yang Dimoderasi oleh Kepemilikan Institusional}

Berdasarkan hasil uji, dapat dilihat bahwa kepemilikan institusional tidak terbukti berpengaruh dalam memperkuat pengaruh negatif antara pertumbuhan perusahaan terhadap financial distress baik dengan model Grover maupun model Springate sehingga $\mathrm{H}_{0}$ diterima dan $\mathrm{H}_{\mathrm{a} 5}$ ditolak. Hal ini dikarenakan seringkali pihak institusi tidak melakukan fungsi pengawasan sebagaimana mestinya sehingga pengawasan terhadap manajemen cenderung lemah. Kepemilikan institusional yang besar belum tentu efektif dalam memonitor perilaku manajer dalam perusahaan karena investor institusional hanya sekadar melakukan investasi untuk memperoleh keuntungan semata seperti dividen, tanpa melakukan pengawasan terhadap manajer dalam meningkatkan penjualan agar laba yang dihasilkan meningkat. Hal tersebut dapat meningkatkan kemungkinan perusahaan mengalami kesulitan keuangan. Hasil penelitian ini tidak mendukung teori agensi yang menyatakan bahwa masalah yang muncul pada suatu perusahaan dapat terjadi karena adanya hubungan keagenan. Apakah pihak agen telah bekerja sesuai kontrak dan adanya ketidaktahuan prinsipal mengenai ketepatan dari setiap keputusan yang diambil oleh agen. Oleh karena itu, dibutuhkan pengawasan dari pihak luar 
seperti institusi untuk mengawasi kegiatan operasional yang dilakukan manajemen.

\section{Kesimpulan Dan Saran}

Berdasarkan hasil penelitian dapat diambil kesimpulan bahwa terdapat terdapat cukup bukti leverage cenderung berpengaruh positif terhadap financial distress baik dengan model Grover maupun model Springate, pertumbuhan perusahaan cenderung berpengaruh negatif terhadap financial distress dengan model Springate, dan kepemilikan institusional cenderung memperlemah pengaruh leverage terhadap financial distress dengan model Springate. Di sisi lain, tidak terdapat cukup bukti bahwa pertumbuhan perusahaan cenderung berpengaruh negatif terhadap financial distress dengan model Grover. Kepemilikan manajerial tidak berpengaruh dalam memoderasi hubungan leverage dan pertumbuhan perusahaan terhadap financial distress baik dengan model Grover dan model Springate. Kepemilikan institusional tidak berpengaruh dalam memoderasi hubungan leverage terhadap financial distress dengan model Grover. Kepemilikan institusional tidak berpengaruh dalam memoderasi hubungan pertumbuhan perusahaan terhadap financial distress baik dengan model Grover maupun model Springate.

Adapun beberapa saran yang dapat Penulis berikan bagi perusahaan-perusahaan yaitu agar perusahaan berhati-hati dan mempertimbangkan keputusan dalam mengambil pinjaman kepada pihak ketiga agar perusahaan dapat terhindar dari kesulitan keuangan. Perusahaan yang tidak memiliki investor institusional dapat meningkatkan jumlah kepemilikan institusional agar investor institusional dapat mengawasi tindakan manajemen dalam mengelola perusahaan yang berkaitan dengan hutang.

Bagi penelitian selanjutnya disarankan dapat mengukur financial distress menggunakan proksi lain. Proksi lain yang dapat digunakan adalah Altman, Fulmer, Ohlson, dan Zmijewski. Peneliti selanjutnya juga dapat menggunakan variabel lain, seperti ekonomi makro (inflasi, nilai tukar, suku bunga), diversifikasi, dan komponen good corporate governance lainnya. Peneliti selanjutnya juga dapat mengganti proksi variabel leverage yang dalam penelitian ini menggunakan proksi Debt to Equity Ratio menjadi long term debt, serta dapat menggunakan sektor lain selain manufaktur seperti perusahaan jasa atau perbankan yang terdaftar di BEI.

\section{Daftar Pustaka}

Almilia, L. S. K. (2003). Analisis Rasio Keuangan untuk Memprediksi Kondisi Financial Distress Perusahaan Manufaktur yang Terdaftar di Bursa Efek Jakarta, Jurnal Akuntansi dan Auditing Indonesia Vol. 7(2), 183-210. ISSN : 1410-2420.

Aminian, A., Hedayat, M., dan Khoshkho, O. I. (2016). Investigate the Ability of Bankruptcy Prediction Models of Altman and Springate and Zmijewski and Grover in Tehran Stock Exchange, Mediterranean Journal of Social Sciences Vol.7(4), 208214. ISSN : 2039-2117. https://doi.org/10.5901/mjss.2016.v7n4s1p 208

Cadbury Committee. (1992). Report of The Committe on The Financial Aspects of Corporate Governance. London: Gee dan Co. Ltd.

Cooper, D. R., dan Schindler, P. S. (2014). Business Research Methods (12th Edition). New York: McGraw-Hill Education.

Edi, dan Tania, M. (2018). Ketepatan Model Altman, Springate, Zmijewski, dan Grover dalam memprediksi Financial Distress, Jurnal Riset Akuntansi Keuangan Vol. 8(1), (April).

https://doi.org/10.22219/jrak.v8i1.28. ISSN :2088-0685.

Eliu, V. (2014). Pengaruh Financial Leverage dan Firm Growth terhadap Financial Distress,FINESTA Vol. 2(2), 6-11.

Fatmawati, M. (2012). Penggunaan The Zmijewski Model, The Altman Model, dan 
The Springate Model sebagai Prediktor Delisting, Jurnal Keuangan dan Perbankan 16(1), 56-65.

Ghozali, I. (2016). Aplikasi Analisis Multivariete dengan Program (Edisi 8). Semarang: Badan Penerbit Universitas Diponegoro.

Hery. (2016). Financial Ratio for Business. Jakarta: Grasindo.

Iskander, M. R., dan Chamlou, N. (2000). Corporate Governance: A Framework for Implementation.

Jayanti, Q., dan Rustiana. (2015). Analisis Tingkat Akurasi Model-Model Prediksi Kebangkrutan untuk Memprediksi Voluntary Auditor Switching (Studi pada perusahaan manufaktur yang terdaftar di BEI), MODUS Vol. 27(2), 87-108. ISSN : 0852-1875.

Jensen, M. C., dan Meckling, W. H. (1976). Theory of the Firm: Managerial Behavior, Agency Costs and Ownership Structure, 3, $1-76$.

Kasmir. (2015). Analisis Laporan Keuangan. Jakarta: PT Rajagrafindo Persada.

Lizal, L. (2002). Determinants of Financial Distress: What Drives Bankruptcy in a Transition Economy? The Czech Republic Case, (451).

Neldawati. (2018). Pengaruh Good Corporate Governance, Profitabilitas, dan Ukuran Perusahaan terhadap Financial Distress (Studi Empiris pada Perusahaan Manufaktur yang Bergerak di Sektor Aneka Industri dan Barang Konsumsi yang Terdaftar di Bursa Efek Indonesia Periode 2013-2016), JOM FEB Vol. 1(1), 1-15.

Platt, H. D., dan Platt, M. B. (2006). Understanding Diffrences Between Financial Distress and Bankruptcy, Vol. 2(2), 141-157.
Rohmadini, A., Saifi, M., dan Darmawan, A. (2018). Pengaruh Profitabilitas, Likuiditas, dan Leverage terhadap Financial Distress (Studi pada Perusahaan Food dan Beverage yang Terdaftar di Bursa Efek Indonesia Periode 2013-2016 ), Jurnal Administrasi Bisnis Vol. 61(2), 11-19.

Ross, S. A., Westerfield, R. W., dan Jaffe, J. (2010). Corporate Finance (9 edition). Singapore: McGraw-Hill Education.

Sugiono, A., dan Untung, E. (2016). Panduan Praktis Dasar (Edisi Revisi). Jakarta: PT Grasindo.

Sujarweni, V. W. (2017). Analisis Laporan Keuangan Teori, Aplikasi, dan Hasil Penelitian. Yogyakarta: Pustaka Baru Press.

Triwahyuningtias, M., dan Muharam, H. (2012). Analisis Pengaruh Struktur Kepemilikan, Ukuran Dewan, Komisaris Independen, Likuiditas dan Leverage terhadap Terjadinya Kondisi Finacial Distress (Studi Pada Perusahaan Manufaktur yang Terdaftar di Bursa Efek Indonesia Tahun 2008-2010), Diponegoro Journal of Management Vol. 1(1), 1-14.

Widarjo, W., dan Setiawan, D. (2009). Pengaruh Rasio Keuangan terhadap Kondisi Financial Distress Perusahaan Otomotif, Jurnal Bisnis dan Akuntansi Vol. 11(2), 107-119.

Widati, L. W., dan Pratama, B. A. (2015). Pengaruh Current Ratio, Debt To Equity Ratio, dan Return on Equity untuk Memprediksi Kondisi Financial Distress. SENDI_UI. ISBN : 978-979-3649-81-8.

Yudadibrata, H. B. N., dan Soenarno, Y. N. (2016). Analisis Rasio Keuangan dan Struktur Kepemilikan Perusahaan dalam Memprediksi Kesulitan Keuangan: Sebuah Riset Empiris pada Perusahaan Nonkeuangan yang Terdaftar di Bursa Efek Indonesia, Jurnal Akuntansi Vol.1, 83-115. 
http://jabar.tribunnews.com/2018/08/31/nilai -tukar-rupiah-melemah-inilah-dampak-yangakan-terjadi-menurut-pengamat-ekonomiunpad?page $=2$

https://www.merdeka.com/uang/4perusahaan-besar-mendadak-bangkrut-ini penyebabnya/pt-sariwangi-pailit-gagalbayar-utang.html https://ekonomi.kompas.com/read/2018/10/1 8/060810426/sariwangi-si-pelopor-tehcelup-di-indonesia-yang-berakhir-tragis

http://kabar24.bisnis.com/read/20171228/16/ 721762/ini-daftar-perusahaan-yang-pailitsepanjang-2017

$\underline{\text { web.idx.id }}$

WwW.sahamok.com 
LAMPIRAN 1

Hasil Uji SPSS 20

A. Hasil Statistik Deskriptif

1. Hasil Statistik Deskriptif

\begin{tabular}{|l|rr|r|r|r|}
\hline & N & Minimum & Maximum & Mean & Std. Deviation \\
\hline LEV & 210 & .07613 & 4.86956 & .9871173 & .85280712 \\
GROWTH & 210 & -.50001 & .54011 & .0308994 & .13706473 \\
KM & 210 & .00000 & .73930 & .0542980 & .12689262 \\
KI & 210 & .00000 & .99430 & .6682806 & .21728901 \\
FD_GROVER & 210 & 0 & 1 & .05 & .213 \\
FD_SPRINGATE & 210 & 0 & 1 & .43 & .496 \\
Valid N [listwise) & 210 & & & & \\
\hline
\end{tabular}

Sumber :Hasil Uji SPSS 20

\section{Hasil Frekuensi FD_GROVER}

FD_GROVER

\begin{tabular}{|l|r|r|r|r|}
\hline & Frequency & Percent & Valid Percent & $\begin{array}{c}\text { Cumulative } \\
\text { Percent }\end{array}$ \\
\hline \multirow{2}{*}{ Valid Fon Financial Distress } & 200 & 95.2 & 95.2 & 95.2 \\
& 10 & 4.8 & 4.8 & 100.0 \\
\hline
\end{tabular}

Sumber : Hasil Uji SPSS 20

\section{Hasil Frekuensi FD_SPRINGATE}

\begin{tabular}{|l|r|r|r|r|}
\hline & Frequency & Percent & Valid Percent & $\begin{array}{c}\text { Cumulative } \\
\text { Percent }\end{array}$ \\
\hline \multirow{2}{*}{ Valid Non Financial Distress } & 120 & 57.1 & 57.1 & 57.1 \\
& 90 & 42.9 & 42.9 & 100.0 \\
\hline & 210 & 100.0 & 100.0 & \\
\hline
\end{tabular}

Sumber : Hasil Uji SPSS 20 


\section{B. Hasil Uji Menilai Keseluruhan Model (Overall Model Fit)}

\section{Uji Menilai Keseluruhan Model (Overall Model Fit) FD_GROVER}

\section{a. Model 1}

\begin{tabular}{|c|c|c|c|c|c|}
\hline \multirow{2}{*}{\multicolumn{2}{|c|}{ Iteration }} & \multirow{2}{*}{$\begin{array}{c}-2 \text { Log } \\
\text { likel ihood }\end{array}$} & \multicolumn{3}{|c|}{ Coefficients } \\
\hline & & & Constant & LEV & GROWTH \\
\hline \multirow{7}{*}{ Step 1} & 1 & 93.842 & -2.110 & .323 & -.578 \\
\hline & 2 & 70.402 & -3.284 & .670 & -1.438 \\
\hline & 3 & 65.799 & -4.069 & .922 & -2.379 \\
\hline & 4 & 65.387 & -4.383 & 1.017 & -2.843 \\
\hline & 5 & 65.382 & -4.424 & 1.029 & -2.908 \\
\hline & 6 & 65.382 & -4.425 & 1.029 & -2.909 \\
\hline & 7 & 65.382 & -4.425 & 1.029 & -2.909 \\
\hline
\end{tabular}

a. Method: Enter

b. Constant is included in the model.

c. Initial -2 Log Likelihood: 80.407

d. Estimation terminated at iteration number 7 because parameter estimates changed by less than .001.

Sumber : Hasil Uji SPSS 20

b. Model 2

Iteration History ${ }^{\mathrm{a}, \mathrm{b}, \mathrm{c}, \mathrm{d}}$

\begin{tabular}{|c|c|c|c|c|c|c|c|}
\hline \multicolumn{2}{|c|}{ Iteration } & \multirow{2}{*}{$\begin{array}{c}-2 \text { Log } \\
\text { likelihood }\end{array}$} & \multicolumn{5}{|c|}{ Coefficients } \\
\hline & & & Constant & LEV & GROWTH & KM & $\mathrm{KI}$ \\
\hline \multirow{7}{*}{ Step 1} & 1 & 93.312 & -2.051 & .299 & -.568 & .621 & -.104 \\
\hline & 2 & 70.077 & -2.993 & .615 & -1.384 & .533 & -.400 \\
\hline & 3 & 65.547 & -3.450 & .875 & -2.307 & -.173 & -.835 \\
\hline & 4 & 65.111 & -3.576 & .989 & -2.775 & -.665 & -1.109 \\
\hline & 5 & 65.104 & -3.585 & 1.006 & -2.842 & -.752 & -1.161 \\
\hline & 6 & 65.104 & -3.585 & 1.006 & -2.843 & -.754 & -1.162 \\
\hline & 7 & 65.104 & -3.585 & 1.006 & -2.843 & -.754 & -1.162 \\
\hline
\end{tabular}

a. Method: Enter

b. Constant is included in the model.

c. Initial -2 Log Likelihood: 80.407

d. Estimation terminated at iteration number 7 because parameter estimates changed by less than .001 .

Sumber : Hasil Uji SPSS 20 


\section{c. Model 3}

\begin{tabular}{|c|c|c|c|c|c|c|c|c|c|c|}
\hline \multirow[t]{2}{*}{ Iteration } & \multirow{2}{*}{$\begin{array}{c}-2 \text { Log } \\
\text { likelihood }\end{array}$} & \multicolumn{9}{|c|}{ Coefficients } \\
\hline & & Constant & LEV & $\begin{array}{c}\text { GROW } \\
\text { TH }\end{array}$ & KM & $\mathrm{KI}$ & $\begin{array}{c}\mathrm{LEV}_{-} \\
\mathrm{KM}\end{array}$ & LEV_KI & $\begin{array}{c}\text { GROWT } \\
\text { H_KM }\end{array}$ & $\begin{array}{c}\text { GROWT } \\
\text { H_KI }\end{array}$ \\
\hline \multirow{9}{*}{ Step 1} & 89.201 & -1.872 & .295 & -1.837 & -1.332 & -.130 & .654 & -.158 & 10.259 & .996 \\
\hline & 65.107 & -2.836 & .669 & -3.570 & -2.744 & -.243 & .878 & -.315 & 18.659 & 1.396 \\
\hline & 59.802 & -3.317 & .868 & -4.693 & -5.390 & -.544 & 1.488 & -.262 & 25.800 & .881 \\
\hline & 58.891 & -3.273 & .819 & -4.465 & -9.622 & -.943 & 2.612 & -.082 & 29.360 & -.344 \\
\hline & 58.713 & -3.179 & .784 & -4.170 & 13.805 & -1.071 & 3.655 & -.030 & 30.648 & -.838 \\
\hline & 58.688 & -3.159 & .779 & -4.107 & $16.087^{-}$ & -1.075 & 4.208 & -.027 & 30.659 & -.906 \\
\hline & 58.687 & -3.157 & .778 & -4.101 & 16.551 & -1.075 & 4.318 & -.027 & 30.525 & -.910 \\
\hline & 58.687 & -3.157 & .778 & -4.101 & 16.566 & -1.075 & 4.322 & -.027 & 30.517 & -.910 \\
\hline & 58.687 & -3.157 & .778 & -4.101 & 16.566 & -1.075 & 4.322 & -.027 & 30.517 & -.910 \\
\hline
\end{tabular}

a. Method: Enter

b. Constant is included in the model.

c. Initial -2 Log Likelihood: 80.407

d. Estimation terminated at iteration number 9 because parameter estimates changed by less than .001 .

Sumber : Hasil Uji SPSS 20

\section{Uji Menilai Keseluruhan Model (Overall Model Fit) FD_SPRINGATE}

\section{Iteration History ${ }^{\mathrm{a}, \mathrm{b}, \mathrm{c}, \mathrm{d}}$}

\begin{tabular}{|rl|r|r|r|r|}
\hline \multicolumn{1}{|l|}{ Iteration } & \multicolumn{1}{c|}{$\begin{array}{c}\text {-2 Log } \\
\text { likelihood }\end{array}$} & \multicolumn{3}{|c|}{ Coefficients } \\
\cline { 4 - 6 } & & Constant & \multicolumn{1}{c|}{ LEV } & \multicolumn{1}{c|}{ GROWTH } \\
\hline \multirow{3}{*}{ Step 1 1} & 3 & 237.155 & -1.160 & .985 & -3.152 \\
& 2 & 232.934 & -1.516 & 1.401 & -4.240 \\
& 4 & 232.802 & -1.589 & 1.493 & -4.438 \\
& 5 & 232.802 & -1.591 & 1.496 & -4.444 \\
& 5 & 232.802 & -1.591 & 1.496 & -4.444 \\
\hline
\end{tabular}

a. Method: Enter

b. Constant is included in the model.

c. Initial -2 Log Likelihood: 286.821

d. Estimation terminated at iteration number 5 because parameter estimates changed by less than .001 .

Sumber : Hasil Uji SPSS 20 
a. Model 1

b. $\quad$ Model 2

Iteration History $\mathbf{a}^{\mathrm{a}, \mathrm{b}, \mathrm{c}, \mathrm{d}}$

\begin{tabular}{|c|c|c|c|c|c|c|c|}
\hline \multirow{2}{*}{\multicolumn{2}{|c|}{ Iteration }} & \multirow{2}{*}{$\begin{array}{c}-2 \text { Log } \\
\text { likelihood }\end{array}$} & \multicolumn{5}{|c|}{ Coefficients } \\
\hline & & & Constant & LEV & GROWTH & KM & KI \\
\hline \multirow{5}{*}{ Step 1} & 1 & 232.568 & -.251 & 1.068 & -3.193 & -3.291 & -1.213 \\
\hline & 2 & 229.161 & -.396 & 1.434 & -4.254 & -3.910 & -1.444 \\
\hline & 3 & 229.069 & -.443 & 1.507 & -4.434 & -3.863 & -1.464 \\
\hline & 4 & 229.069 & -.445 & 1.510 & -4.439 & -3.854 & -1.464 \\
\hline & 5 & 229.069 & -.445 & 1.510 & -4.439 & -3.854 & -1.464 \\
\hline
\end{tabular}

a. Method: Enter

b. Constant is included in the model.

c. Initial -2 Log Likelihood: 286.821

d. Estimation terminated at iteration number 5 because parameter estimates changed by less than .001 .

c. Model 3 
Iteration Historya, a, s,

\begin{tabular}{|c|c|c|c|c|c|c|c|c|c|c|}
\hline It eration & \multirow{2}{*}{$\begin{array}{l}-2 \log \\
\text { likelihood }\end{array}$} & \multicolumn{9}{|c|}{ Coefficients } \\
\hline & & Constant & LEV & GROWTH & KM & KI & $\mathrm{LEV}_{-}$ & LEV_KI & $\begin{array}{c}\text { GROWT } \\
H_{-} \text {KM }\end{array}$ & $\begin{array}{c}\text { GROWT } \\
\mathrm{H}_{-} \mathrm{KI}\end{array}$ \\
\hline 1 & 224.232 & $-2.15 B$ & 3.334 & -1.780 & -.304 & 1.411 & 3.060 & -3.124 & -1.041 & -2.155 \\
\hline 2 & 214.941 & -3.924 & 5.802 & -4.862 & 1.115 & 3.228 & 5.501 & -5.761 & -.943 & $.85 B$ \\
\hline 3 & 211.165 & -4.996 & 7.283 & -7.650 & .872 & 4.451 & 5.372 & -7.471 & -4.714 & 4.516 \\
\hline 4 & 204.659 & -4.331 & 6.839 & -7.720 & -8.632 & 3.731 & 5.719 & -7.057 & -13.655 & 4.534 \\
\hline 5 & 202.678 & -4.211 & 6.775 & -7.195 & -16.879 & 3.637 & 14.37 & -7.027 & -34.036 & 3.975 \\
\hline Ste & & & & & & & 21.48 & & & \\
\hline p 1 & 202.167 & -4.142 & 6.674 & -6.860 & -23.048 & 3.577 & 9 & -6.941 & -51.558 & 3.645 \\
\hline 7 & 202.122 & -4.111 & 6.632 & $-6.6 B 2$ & $-25.43 B$ & 3.546 & $\begin{array}{r}24.41 \\
4\end{array}$ & -6.904 & $-5 B .5 B O$ & 3.438 \\
\hline 8 & 202.121 & -4.110 & 6.630 & -6.670 & -25.640 & 3.544 & $\begin{array}{r}24.65 \\
2\end{array}$ & -6.902 & -59.157 & 3.423 \\
\hline 9 & 202.121 & -4.110 & 6.630 & -6.670 & -25.641 & 3.544 & $\begin{array}{r}24.65 \\
3\end{array}$ & -6.902 & -59.160 & 3.423 \\
\hline 10 & 202.121 & -4.110 & 6.630 & -6.670 & -25.641 & 3.544 & $\begin{array}{r}24.65 \\
3\end{array}$ & -6.902 & -59.160 & 3.423 \\
\hline
\end{tabular}

a. Method: Enter

b. Constant is included in the model.

c. In itial -2 Log Likel ihood: 286.821

d. Estimation termin at ed at iteration number 10 because parameter estimates changed by less than .001 .

Sumber : Hasil Uji SPSS 20

\section{Hasil Koefisien Determinasi (Nagelkerke's R Square)}

1. Hasil Koefisien Determinasi (Nagelkerke's R Square) FD_GROVER

a. Model 1

\begin{tabular}{|l|r|r|c|}
\hline Step & $\begin{array}{c}\text { Model Summary } \\
\text { likelihood }\end{array}$ & $\begin{array}{c}\text { Cox dan Snell R } \\
\text { Square }\end{array}$ & $\begin{array}{c}\text { Nagelkerke R } \\
\text { Square }\end{array}$ \\
\hline 1 & $65.382^{\mathrm{a}}$ & .069 & .217 \\
\hline
\end{tabular}

a. Estimation terminated at iteration number 7 because

parameter estimates changed by less than .001 .

Sumber : Hasil Uji SPSS 20

b. Model 2

Model Summary

\begin{tabular}{|l|c|c|c|}
\hline Step & -2 Log & Cox dan Snell R & Nagelkerke R \\
& likelihood & Square & Square \\
\hline
\end{tabular}




\begin{tabular}{|l|r|r|r|}
\hline 1 & $65.104^{\mathrm{a}}$ & .070 & .221 \\
\hline
\end{tabular}

a. Estimation terminated at iteration number 7 because parameter estimates changed by less than .001 .

Sumber : Hasil Uji SPSS 20

c. Model 3

\begin{tabular}{|c|c|c|c|}
\hline \multicolumn{4}{|c|}{ Model Summary } \\
\hline Step & $\begin{array}{c}-2 \text { Log } \\
\text { likelihood }\end{array}$ & $\begin{array}{c}\text { Cox dan Snell R } \\
\text { Square }\end{array}$ & $\begin{array}{l}\text { Nagelkerke R } \\
\text { Square }\end{array}$ \\
\hline 1 & $58.687^{a}$ & .098 & .309 \\
\hline
\end{tabular}

a. Estimation terminated at iteration number 9 because parameter estimates changed by less than .001 .

2. Hasil Koefisien Determinasi (Nagelkerke's R Square) FD_SPRINGATE a. Model 1

\begin{tabular}{|l|r|r|r|}
\hline Step & $\begin{array}{c}|c| \\
-2 \text { Log } \\
\text { likelihood }\end{array}$ & $\begin{array}{c}\text { Cox dan Snell R } \\
\text { Square }\end{array}$ & $\begin{array}{c}\text { Nagelkerke R } \\
\text { Square }\end{array}$ \\
\hline 1 & $232.802^{\mathrm{a}}$ & .227 & .305 \\
\hline
\end{tabular}

a. Estimation terminated at iteration number 5 because parameter estimates changed by less than .001 .

b. Model 2

\begin{tabular}{|l|r|r|c|}
\hline Step & $\begin{array}{c}\mid c \text { Model Summary } \\
\text { likelihood }\end{array}$ & $\begin{array}{c}\text { Cox dan Snell R } \\
\text { Square }\end{array}$ & $\begin{array}{c}\text { Nagelkerke R } \\
\text { Square }\end{array}$ \\
\hline 1 & $229.069^{\mathrm{a}}$ & .240 & .323 \\
\hline
\end{tabular}

a. Estimation terminated at iteration number 5 because parameter estimates changed by less than .001 .

c. Model 3

\section{Model Summary}




\begin{tabular}{|l|r|r|c|}
\hline Step & \multicolumn{1}{|c|}{$\begin{array}{c}-2 \text { Log } \\
\text { likelihood }\end{array}$} & $\begin{array}{c}\text { Cox dan Snell R } \\
\text { Square }\end{array}$ & $\begin{array}{l}\text { Nagelkerke R } \\
\text { Square }\end{array}$ \\
\hline 1 & $202.121^{\mathrm{a}}$ & .332 & .446 \\
\hline
\end{tabular}

a. Estimation terminated at iteration number 10 because parameter estimates changed by less than .001 .

Sumber : Hasil Uji SPSS 20

D. Menguji Kelayakan Model Regresi

1. Hasil Uji Kelayakan Model Regresi FD_GROVER

a. Model 1

Hosmer and Lemeshow Test
\begin{tabular}{|l|r|r|r|}
\hline Step & Chi-square & df & \multicolumn{1}{c|}{ Sig. } \\
\hline 1 & 3.277 & 8 & .916 \\
\hline
\end{tabular}

Sumber : Hasil Uji SPSS 20

b. Model 2

Hosmer and Lemeshow Test

\begin{tabular}{|l|r|r|r|}
\hline Step & Chi-square & Df & \multicolumn{1}{c|}{ Sig. } \\
\hline 1 & 8.765 & 8 & .363 \\
\hline
\end{tabular}

Sumber : Hasil Uji SPSS 20

c. Model 3

\begin{tabular}{|l|r|r|r|}
\hline \multicolumn{1}{|c|}{ Hosmer and Lemeshow Test } \\
\hline Step & Chi-square & Df & \multicolumn{1}{c|}{ Sig. } \\
\hline 1 & 2.869 & 8 & .942 \\
\hline
\end{tabular}

Sumber : Hasil Uji SPSS 20

E. Model Regresi yang Terbentuk (Uji t)

1. Model Regresi yang Terbentuk FD_GROVER 
a. Model 1

Variables in the Equation

\begin{tabular}{|rl|r|r|r|r|r|r|}
\hline & \multicolumn{1}{|c|}{ B } & \multicolumn{1}{c|}{ S.E. } & Wald & Df & \multicolumn{1}{c|}{ Sig. } & Exp(B) \\
\hline \multirow{2}{*}{ Step $1^{\mathrm{a}}$} & LEV & 1.029 & .271 & 14.391 & 1 & .000 & 2.799 \\
& GROWTH & -2.909 & 2.260 & 1.656 & 1 & .198 & .055 \\
& Constant & -4.425 & .613 & 52.037 & 1 & .000 & .012 \\
\hline
\end{tabular}

a. Variable(s) entered on step 1: LEV, GROWTH.

Sumber : Hasil Uji SPSS 20

b. Model 2

Variables in the Equation

\begin{tabular}{|c|c|c|c|c|c|c|c|}
\hline & & B & S.E. & Wald & Df & Sig. & $\operatorname{Exp}(B)$ \\
\hline \multirow{5}{*}{ Step $1^{\mathrm{a}}$} & LEV & 1.006 & .315 & 10.171 & 1 & .001 & 2.734 \\
\hline & GROWTH & -2.843 & 2.250 & 1.597 & 1 & .206 & .058 \\
\hline & KM & -.754 & 3.093 & .059 & 1 & .807 & .471 \\
\hline & $\mathrm{KI}$ & -1.162 & 2.428 & .229 & 1 & .632 & .313 \\
\hline & Constant & -3.585 & 1.768 & 4.113 & 1 & .043 & .028 \\
\hline
\end{tabular}

a. Variable(s) entered on step 1: LEV, GROWTH, KM, KI.

Sumber : Hasil Uji SPSS 20

Variables in the Equation

\begin{tabular}{|ll|r|r|r|r|r|r|}
\hline & \multicolumn{1}{c|}{ B } & \multicolumn{1}{c|}{ S.E. } & Wald & \multicolumn{1}{c|}{ df } & \multicolumn{1}{c|}{ Sig. } & Exp(B) \\
\hline & LEV & .778 & 2.167 & .129 & 1 & .720 & 2.177 \\
Step & GROWTH & -4.101 & 10.591 & .150 & 1 & .699 & .017 \\
$1^{\mathrm{a}}$ & KM & -16.566 & 19.379 & .731 & 1 & .393 & .000 \\
& KI & -1.075 & 4.487 & .057 & 1 & .811 & .341 \\
& LEV_KM & 4.322 & 5.756 & .564 & 1 & .453 & 75.302
\end{tabular}




\begin{tabular}{|l|r|r|r|r|r|r|}
\hline LEV_KI & -.027 & 2.981 & .000 & 1 & .993 & .973 \\
GROWTH_KM & 30.517 & 45.297 & .454 & 1 & .500 & 17918147655351.254 \\
GROWTH_KI & -.910 & 15.636 & .003 & 1 & .954 & .402 \\
Constant & -3.157 & 3.266 & .934 & 1 & .334 & .043 \\
\hline
\end{tabular}

a. Variable(s) entered on step 1: LEV, GROWTH, KM, KI, LEV_KM, LEV_KI, GROWTH_KM, GROWTH_KI.

Sumber : Hasil Uji SPSS 20

c. Model 3

\section{Model Regresi yang Terbentuk FD_SPRINGATE}

a. Model 1

Variables in the Equation

\begin{tabular}{|rl|r|r|r|r|r|r|}
\hline & \multicolumn{1}{c|}{ B } & \multicolumn{1}{c|}{ S.E. } & \multicolumn{1}{c|}{ Wald } & Df & \multicolumn{1}{c|}{ Sig. } & Exp(B) \\
\hline \multirow{2}{*}{ Step $1^{\mathrm{a}}$} & LEV & 1.496 & .274 & 29.873 & 1 & .000 & 4.464 \\
& GROWTH & -4.444 & 1.326 & 11.236 & 1 & .001 & .012 \\
& Constant & -1.591 & .288 & 30.629 & 1 & .000 & .204 \\
\hline
\end{tabular}

a. Variable(s) entered on step 1: LEV, GROWTH.

Sumber : Hasil Uji SPSS 20

b. $\quad$ Model 2 


\begin{tabular}{|c|c|c|c|c|c|c|c|}
\hline & & B & S.E. & Wald & Df & Sig. & $\operatorname{Exp}[\mathrm{B}]$ \\
\hline \multirow{5}{*}{ Step $1^{\prime \prime}$} & LEV & 1.510 & .268 & 31.833 & 1 & .000 & 4.525 \\
\hline & GROWTH & -4.439 & 1.335 & 11.049 & 1 & .001 & .012 \\
\hline & KM & -3.854 & $2.08 B$ & 3.409 & 1 & .065 & .021 \\
\hline & $\mathrm{KI}$ & -1.464 & 1.033 & 2.010 & 1 & .156 & .231 \\
\hline & Constant & -.445 & .784 & .323 & 1 & .570 & .641 \\
\hline
\end{tabular}

a. Variable[s] entered on step 1: LEV, GROWTH, KM, KI.

\section{c. Model 3}

Variables in the Equation

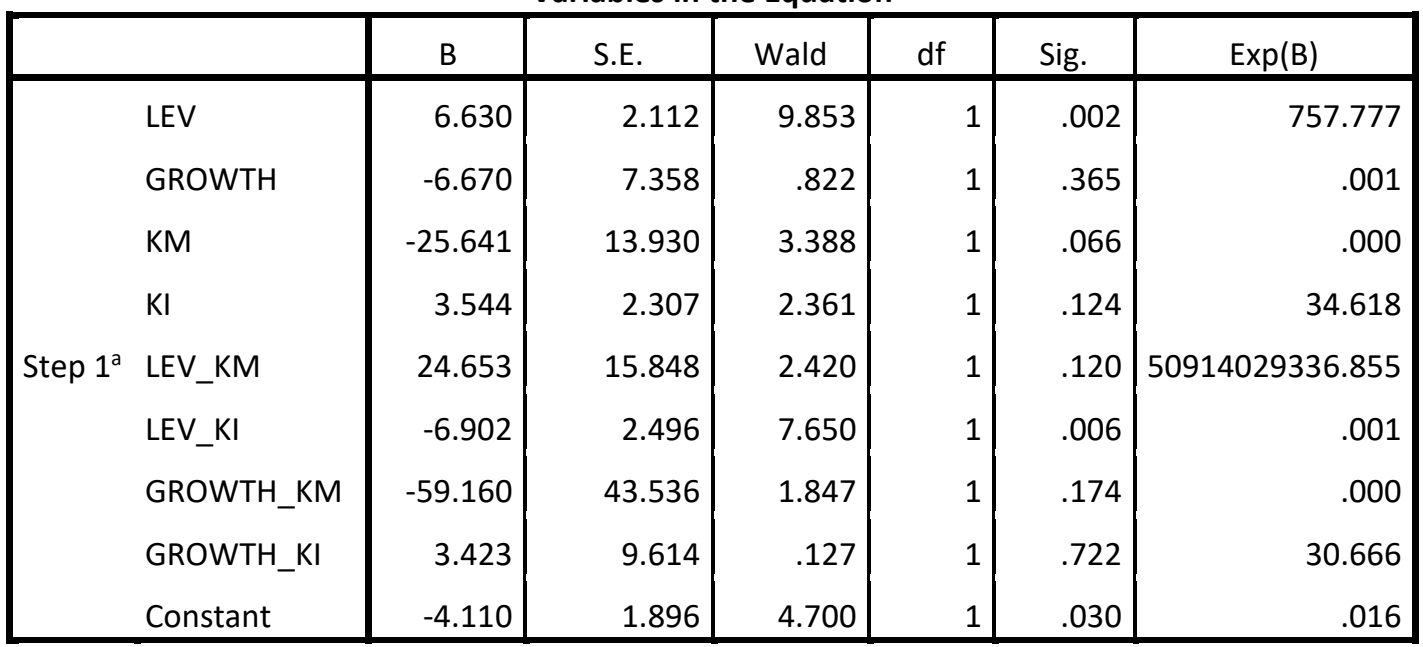

a. Variable(s) entered on step 1: LEV, GROWTH, KM, KI, LEV_KM, LEV_KI, GROWTH_KM, GROWTH_KI.

Sumber : Hasil Uji SPSS 20 